\title{
Sürdürülebilir Kentleşme: Dokuma Kenti Buldan Örneği
}

\author{
Gizem ERDOĞAN ${ }^{1}$, Büşra ÖZTÜRK ${ }^{2 *}$ \\ ORCID 1: 0000-0002-1376-6457 \\ ORCID 2: 0000-0001-9449-0431 \\ 1 İzmir Demokrasi Üniversitesi, Mimarlık Fakültesi, Şehir ve Bölge Planlama Bölümü, 35140, İzmir, Türkiye. \\ 2 Pamukkale Üniversitesi, Mimarlık ve Tasarım Fakültesi, Şehir ve Bölge Planlama Bölümü, 20160, Denizli, Türkiye. \\ *e-mail: gizemerdogan@gmail.com \\ Öz \\ Kentlerde meydana gelen kentsel yığılmalara bağlı olarak gelişen sağlıksız mekânların oluşması, arazi \\ kullanımının sağlıksız biçimde genişlemesi kentsel sürdürülebilirlik kavramını gündeme getirmiştir. Sürdürülebilir \\ kentleşme mekânsal gelişme hedeflenirken bugünün ihtiyaçlarını gelecek kuşakların kendi ihtiyaçlarını \\ karşılamasına mâni olmayacak yöntemlerle karşılayan, koruma-kullanma dengesi kavramına atıfta bulunarak \\ tanımlanmaktadır. Sürdürülebilir kentleşme konusunda yapılmış kayda değer pek çok çalışma, sürdürülebilir \\ kentleşmeye dair 40'tan fazla gösterge ortaya koymuştur. Çevresel süreç olarak bakıldığında ise, mevcut kaynak \\ akışındaki kısıtlamaların dikkate alınarak tabii kaynakların bilinçli ve bilinçsiz tüketiminin ortadan kaldırılması \\ bugün ve gelecek kuşak adına önem teşkil etmektedir. Bu araştırmanın amacı, sürdürülebilir kentleşme üzerine \\ yapılan araştırmalar ışığında sürdürülebilirlik prensiplerini genel hatları ile ortaya koymaktır. Çalışma konusu \\ olan Buldan yerleşkesi planlama alanında sürdürülebilir kentleşme prensipleri temelinde mekânsal, çevresel, \\ ekonomik ve kültürel politikalarının ve yol haritasının oluşturulması hedeflenmiştir. Araştırma, stratejik \\ mekânsal yaklaşımı temel alan yöntem kurgusu temelinde, arazi tespit ve gözlem çalışmaları çerçevesi ve GZFT \\ analizi ışığında ele alınmıştır. Araş̧ırmanın sonunda, tarihte dokuma kenti olarak değerlendirilen Buldan \\ yerleşmesi bütününde sürdürülebilir bir kentleşme modeli tanımlanabilmiştir. Bu model sürdürülebilir gelişme \\ kavramında kent plancılara ve karar alıcılara rehberlik edebilecek çevresel, mekânsal, ekonomik ve kültürel \\ bileşenlerden oluşan bütünleşik bir plan kurgusunu içermektedir.
}

Anahter Kelimeler: Sürdürülebilirlik, sürdürülebilir kentleşme prensipleri, Buldan

\section{Sustainable Urbanization: a Study of a Textile Town Buldan}

\begin{abstract}
The development of unhealthy places due to urban accumulation in urban areas and the unhealthy expansion of land use have brought about the concept of urban sustainability. Sustainable urbanization is defined by the concept of conservation-utilization balance, which provides today's needs with methods that will not prevent future generations from meeting their own needs when spatial development is targeted. Various studies on sustainable urbanization have produced more than 40 indicators of sustainable urbanization. The conscious and unconscious consumption of natural resources has been lifted in consideration of the limitations of the current resource flow, which is important for the present and future generations. The aim of this research is to outline the principles of sustainability in the light of researches on sustainable urbanization in general terms. In the field
\end{abstract}

Atıf: Erdoğan, G., Öztürk, B. (2019). Sürdürülebilir Kentleşme: Dokuma Kenti Buldan Örneği. Mimarlık Bilimleri ve Uygulamaları Dergisi (MBUD), 4 (1), 51-68.

DOI: $10.30785 / \mathrm{mbud} .443568$ 
of Buldan settlement planning, which is the subject of the study, it is aimed to create spatial, environmental, economic and cultural policies and determine road map on the basis of sustainable urbanization principles. The research is based on the methodology based on strategic spatial approach, the field survey and observational studies framework and SWOT analysis. A sustainable model of urbanization has been defined throughout Buldan settlement, which is considered as a textile settlement in history. This model includes an integrated plan formulation of environmental, spatial, economic and cultural components that can guide urban planners and decision makers in the concept of sustainable development.

Keywords: Sustainability, principles of sustainable urbanization, Buldan

\section{Giriş}

Kentlerde meydana gelen kentsel yığılmalar, iş olanaklarının çeşitlendiği bölgelerde artmaktadır. Kentsel yığılmalara bağlı olarak gelişen sağııksız mekânların oluşması, arazi kullanımının sağlıksız biçimde genişlemesi ve yayılması kentsel sürdürülebilirlik kavramını gündeme getirmiştir. Sürdürülebilirlik kavramı, Bruntland raporu ve Rio bildirgesinde, 'günümüz gereksinimlerini, gelecek nesillerin gereksinimlerini temin etme olanaklarından ödün vermeksizin karşılamak' olarak ifade edilmiş olup, ilişkili olan ekonomik, çevresel, sosyal-kültürel alanlar birbirleri ile bağlantılıdır (Gazibey vd., 2014; Johnson, 2009; Yiğitcanlar ve Teriman, 2015;). Günümüz kentlerinde hızlı ve kontrolsüz nüfus yoğunluklarının neden olduğu sağlıksız mekânların oluşması, dengesiz arazi kullanımı ve kentsel yığılmalardan kaynaklı sürdürülebilir kentleşme kavramı dâhilinde politika ve stratejiler oluşturma bağlamında çözüm arayışları gereksinimi doğmuştur. Sürdürülebilir kentleşme gereklerini yerine getirebilme adına ekonomik, toplumsal ve çevresel gelişme ilkelerinin entegrasyonu sağlanarak, etkileşimlerinin yükseltilerek kendi içerisinde başarabilme teknikleri ile olası hale getirilmesi sağlanmalıdır (Tuğun ve Karaman, 2014; Özcan, 2016). Kentlerde güvenilir mekan, enerji ve kaynaklarını yerinde, etkin, verimli kullanan topluluklar, yerel ve kültürel değerlerin gelecek nesillerin hakkını da koruyacak ve yerel ürünler sisteminin sahip çıkılarak korunması, atık-geri dönüşüm dengesinin benimsenmesi yaklaşımlarının sürdürülebilir kentleşme gereklerinin yerine getirilmesi için gerçekleştirilmesi gereken politika ve stratejiler olduğuna dair çalışmalar bulunmaktadır (Tosun, 2009; Mansuroğlu vd., 2012; İnceoğlu, 2013; Desheng vd., 2014; Tuğun ve Karaman, 2014; Özcan, 2016; Medved, 2016).

Araştırmanın amacı, sürdürülebilir kentleşme üzerine yapılan araştırmalar ışığında sürdürülebilirlik prensiplerini ortaya koymak ve çalışma alanı üzerinde bu değerleri değerlendirmektir. Çalışmanın konusu, Buldan yerleşmesinin kentsel kimlik ve ekonomisinde önemli yer edinmiş olan aile ölçeğinde ve elektrikli makinelerden yararlanmayan, geleneksel tarzda, el işçiliği ile üretim yapan, günümüzde ise kaybolmaya ve gerilemeye yüz tutmuş bulunan dokumacılığın desteklenmesi hedefi ile yerel ve kültürel değerlerini yaşatma adına, yerleşmede bulunan sorun ve riskler üzerinden sürdürülebilir kentleşme temelinde mekânsal, çevresel, ekonomik ve kültürel politikaların oluşturulmasıdır.

$\mathrm{Bu}$ hedefle çalışma 5 (beş) aşamada kurgulanmıştır. Birinci aşama sürdürülebilir kentleşme kavramının tanımı üzerinden sürdürülebilir kentleşme gerekleri irdelenecektir. İkinci aşamada çalışma alanına mevcut durum tanımı gerçekleştirilecek elde edilen veriler ortaya konulacaktır. Üçüncü aşamada mekânda yakalanan tespitler doğrultusunda mevcut durum değerlendirilmesine yönelik potansiyel ve risk değerlendirmesi yapılarak, mekânsal, ekonomik, kültürel, ekolojik ve kurumsal yapı üzerinden Güçlü-Zayıf Yönler-Fırsatlar-Tehditler (GZFT) analizi gerçekleştirilecektir. Dördüncü aşamada mekânda saha çalışmaları boyunca elde edilen veriler eşliğinde, sorun ve riskler üzerinden mekânsal, ekonomik, sosyo-kültürel, çevresel bileşenlerine oturan yaklaşım ve kararlar önerilecektir. Son olarak sonuç bölümünde araştırma çalışmasından elde edilen veriler doğrultusunda Buldan yerleşmesinin sürdürülebilir olmasına dönük oluşturulan model kurgusu temelli öneriler sunulacaktır.

Araştırma, kırsal yerleşmelerin sahip olduğu ulusal ve uluslararası değerleri açısından sürdürülebilir kentleşme sağlanmasına yönelik politika ve stratejilerin geliştirilmesi, yeni modeller kurgulanması açısından önem taşımaktadır. Bu yönüyle, sürdürülebilir kentleşme üzerine yapılan tartışmalar, araştırmalar ve karar alıcılar tarafından kurgulanan planlama ve uygulama çalışmalarına yöntem tasarımı açısından katkı sağlayacağı düşünülmektedir. 


\subsection{Kavramsal Arka Plan}

\subsubsection{Sürdürülebilir kentleşme}

Kentleşmenin hızlı temposu nedeniyle, şehirler giderek doğal ekosistemlerin yerini almaktadır (Attwell, 2000, United Nations Population Fund, 2007). Bu olumsuzluk ortamında sürdürülebilirlik kavramı, mekânsal, ekonomik, sosyo-kültürel, çevresel, kurumsal ihtiyaçların birbirleri ile çelişmeden, tümünün uyum içerisinde olduğu, toplum yararının gözetildiği, evrensel çözüm önerilerini kapsayan koruma-kullanma dengesinin benimsendiği, tüm kesim için eşitlik ilkesinin temel esas alındığı kavram olarak tanımlanmaktadır (Ekim, 2004; Temur, 2011; Çal, 2012). Sürdürülebilir kentleşme kavramı ise; ekolojik unsurların önemli olduğu mekânsal gelişme gündeminde, bugünün ihtiyaçlarını gelecek kuşakların kendi ihtiyaçlarını karşılamasına mâni olmayacak yöntemlerle karşılamak (Anonim, 1987) ilkesi etrafında koruma-kullanma dengesine atıfta bulunarak tanımlanmaktadır. Sürdürülebilir kentleşme sürdürülebilir kalkınma ilkelerini karşılayan bir kentleşme sürecini tanımlar (Roy, 2009). Dünyada hızı nüfus artışı, kontrolsüz arazi kullanımı ile çevreye aktarılan sorunlarla beraber, sağlıksız yaşam koşullarının oluşması, kentlerde meydana gelen yığılmalar ve beraberinde getirdiği yoksulluğun artması, biyolojik çeşitliliğin zarar görmesine neden olup, beslenme problemleriyle beraber kıtlık sorunlarının ortaya çıkmasından kaynaklı sürdürülebilir kentleşme adına çözüm önerileri getirilmesi bağlamında stratejiler oluşturulması gerektiği ifade edilmiştir (Karakuzulu, 2010; Özcan, 2016). Kavramın ortaya çıkması ile birlikte sürdürülebilir kentleşmenin sağlanmasında bugün ve gelecek nesiller için yaşam kalitesinin geliştirilmesi öngörülerek, istihdam ve kıtlık sorunlarının çözümü, yoksulluğun ortadan kaldırılması, sosyal ve kültürel değerlere sahip çıkan, mevcut doğal değer ve kaynakların sürdürülebilir kullanımını destekleyen politikalar üretilme gerekliliği ortaya konulmuştur (Tosun, 2009; İnceoğlu, 2013).

Sürdürülebilir kentleşme konusunda yapılmış kayda değer pek çok çalışma vardır (May, Mitchell, and Kupiszewska 1997; Özcan, 2009; Tosun Karakurt, 2009; Eser vd., 2012; Mansuroğlu vd., 2012; Shen vd., 2012; Desheng vd., 2014; Gazibey vd., 2014; Karakuzulu, 2010; Liv vd., 2014 Maimaitiyiming vd.,2014; Tuğun ve Karaman, 2014; Wu, 2014; Yiğitcanlar ve Teriman, 2015; Medved, 2016; Özcan, 2016; Broman ve Robert, 2017; Siiba vd., 2018). Sürdürülebilirlik kent için ortaya konan 'Nicel Şehir Model'i sürdürülebilir kenti fiziksel çevre, kaynaklar, sağlık, güvenlik, hizmetler ve altyapı ve topluluk gelişimi olmak üzere altı perspektif üzerinden tanımlamıştır (May, Mitchell, and Kupiszewska 1997). Buna karşın Shen ve Zhou sosyal, ekonomik, çevresel ve kurumsal göstergeler olmak üzere dört boyutta hiyerarşik olarak yapılandırımıştır (Shen ve Zhou, 2014). BM üye ülkelerinin 2000 yılında kabul ettikleri Binyıl Kalkınma Hedefleri (MDG) sürdürülebilir kentleşmeye dair 40'tan fazla gösterge ortaya koymuştur. Bütün bu göstergeler, barınma, sosyal kalkınma ve yoksulluğun ortadan kaldırılması, çevre yönetimi, ekonomik kalkınma ve yönetişim olmak üzere beş kategoriyi kapsamaktadır (UN, Habitat, 2009). Kentsel sürdürülebilirliği incelemek için kullanılan yöntemler çeşitli olsa da ortak ilkeyi barındırırlar: kentsel sürdürülebilirlik, bir şehrin ekonomik, sosyal ve ekolojik gelişimi açısından değerlendirilmelidir (Burgess et al., 1997, Harris, 1992, Marcotullio, 2001).

Sürdürülebilir kentleşmenin sağlanması için önerilen politikalar sürdürülebilir tabii kaynak kullanımının desteklenerek, dengeli nüfus artışının sağlanması, yürümeye teşvik, bisiklet sürme ve toplu taşıma sistemine özendirme ile enerji tasarrufu sağlanması ve yoksulluğun ortadan kaldırılması temelinde kurgulanmaktadır (Desheng vd., 2014). Sürdürülebilir kentleşme çevresel ilkeler temelinde ve kentlerin refahını sağlama hedefi ile dengeli ekonomik gelişme sağlanmalı, atık-geri dönüşüm döngüsü ile çevresel değerlerin dikkate alınıp, korunduğu, minimum hava kirliliğine sahip, ekolojik ayak izinin en aza indirgendiği yaklaşımın benimsenmesi gerekmektedir (Gazibey vd., 2014). Kentlerde ve planlama aşamasında sürdürülebilirliği sağlamak için ekosistemlerin fonksiyonları tayin edilmeli ve birbirleri ile olan etkileşimlerinin sürekliliği sağlanmalı, doğal ve kültürel değerler bağlamında stratejiler üretilmeli (Mansuroğlu vd., 2012) ve bu veriler ışığında bilimsel ve teknik gerekçelere dayanan gelişim alanlarının önerilmesi gerekmektedir. Sürdürülebilir kentlerin, çevresel ilkeler ve kentlerin refahını sağlama bağlamında dengeli ekonomik gelişmesini sağlamış, atık-geri dönüşüm döngüsü ile çevresel değerlerin dikkate alınarak, korunmuş, minimum hava kirliliğine sahip, 
ekolojik ayak izinin en aza indirgendiği yaklaşımların benimsendiği, erişilebilir ulaşım olanakları tanıyan, doğal yaşama ortamlarının korunduğu kentler olması gerekmektedir (Gazibey vd., 2014). Yukarıda bahsedilenlerin yanı sıra sürdürülebilir kullanımı güvence altına almak ve sürdürmek için tasarlanmış alternatif tabii kaynaklar oluşturularak yenilenebilir enerji sisteminin oluşturulması, yerel ve kültürel değerlerin, gelecek nesillerin de hak ve yararı gözetilecek şekilde düşünülerek yerel ürünler sistemi oluşturulması amacı ile toplumun değerlerinin güvence altına alınması ve bu amaca yönelik hedefler bağlamında toplum kimliğine sahip çıkacak stratejilerin gerekliliği de değerlendirilmektedir (Medved, 2016). Tabii ve kültürel değerlerin sürdürülebilir kılınmasına, yenilenebilir enerji kaynakların kullanımının sağlanması ve kaynakların yerinde, etkin ve verimli kullanımının desteklenmesi ile geri dönüşüm veya yeniden kullanım imkanının benimsendiği, yaşam kalitesinin artırılması adına sağlıklı mekanların oluşturulmasına dönük hedefler ortaya konulmasının önemi (Özcan, 2016) ve sürdürülebilir kentleşmeyi sağlamak için kalkınma süreçleri ile entegre çalışılması gerektiği ve 3 aşamalı planlama, kalkınma ve ekosistem sürdürülebilirliği ile bir planlama süreci oluşturularak, bu düşüncenin planın her aşamasında olması ve bu aşamalar dahilinde gerekli politikaların da üretilerek mekana yansıması gerektiğine dair yöntemsel yaklaşımlar da değerlendirilmektedir (Yiğitcanlar ve Teriman, 2015). Kentte sürdürülebilir kentleşmenin sağlanması adına sağlıksız yaşam koşullarının çevre düzenlemeleri ile giderilmesi, eşitlik esasının temel alındığı ortaya çıkan kentsel yoksunluk ve yoksulluğun tamamen ortadan kaldırılması, istihdam sorunları ve beslenme sorunlarının çözümüne yönelik sosyal ve kültürel değerlere sahip çıkan, mevcut doğal değer ve kaynakların sürdürülebilir kullanımını destekleyen değerler bütünü kapsamında yörenin yerel ve kültürel değerlerinin korunarak gelecek nesillerin hak ve yararı gözetilmesi bağlamında ele alınması gerektiği ifade edilmiştir (Karakuzulu, 2010; Özcan, 2016; Tosun, 2009; Inceoğlu, 2013; Medved, 2016; Eser vd., 2010; Özcan, 2009). Özetle, sürdürülebilirlik prensipleri temelde çevresel, mekânsal, ekonomik ve kültürel yapı üzerinden okunabilir (Çizelge 1).

Çizelge 1. Sürdürülebilirlik prensipleri

\begin{tabular}{|c|c|c|}
\hline YAKLAŞIMLAR & PRENSIPLER & YAZAR \\
\hline \multirow{3}{*}{ ÇEVRESEL } & $\begin{array}{l}\text { Biyolojik çeşitliliğin korunması, beslenme ve } \\
\text { temiz-sağlıklı su bulmanın göz önünde } \\
\text { bulundurulması ile sağılılı ve güvenilir } \\
\text { mekânların oluşturulması }\end{array}$ & $\begin{array}{l}\text { Medved, 2016; Özcan, 2016; Gazibey vd., } \\
\text { 2014; Tuğun ve Karaman, } 2014\end{array}$ \\
\hline & $\begin{array}{l}\text { Üretim ve tüketimde ekolojik ayak izinin en aza } \\
\text { indirgendiği ve sera gazının kontrol altında } \\
\text { tutulduğu yaklaşımlar benimsenmelidir }\end{array}$ & Maimaitiyiming, 2014; Gazibey vd., 2014 \\
\hline & $\begin{array}{l}\text { Atık-geri dönüşüm döngüsünün kurularak } \\
\text { yeniden kullanım olanaklarının ele alındığı bir } \\
\text { sistem kurgusu geliştirilmesi }\end{array}$ & $\begin{array}{l}\text { Liv vd., 2014; Özcan, 2016; Medved, 2016; } \\
\text { Tosun, 2009; Tuğun ve Karaman, } 2014\end{array}$ \\
\hline \multirow{2}{*}{ MEKÂNSAL YAPIYA DAIR } & $\begin{array}{l}\text { Kontrollü arazi kullanımı ile dengeli ekonomik } \\
\text { büyümenin sağlanması adına kaynakların etkin } \\
\text { ve verimli kullanılarak yoksulluğun giderilmesi }\end{array}$ & $\begin{array}{l}\text { Karakuzulu 2010; Özcan, 2016; Tosun, 2009; } \\
\text { İnceoğlu, 2013; Desheng vd., 2014; Tuğun } \\
\text { ve Karaman, } 2014\end{array}$ \\
\hline & $\begin{array}{l}\text { Ulaşımda ekolojik ayak izi düşürmek, bisiklet } \\
\text { kullanımını artırmak, yürüme ve toplu taşıma } \\
\text { sisteminin özendirilmesi }\end{array}$ & $\begin{array}{l}\text { Medved, 2016; Desheng vd., 2014; Özcan, } \\
2016\end{array}$ \\
\hline \multirow{2}{*}{ EKONOMIK YAPIYA DAIR } & $\begin{array}{l}\text { Üretim ve tüketimde değişen, yenilenen } \\
\text { teknolojiye karşılık, geri kalmaksızın yeni } \\
\text { teknolojik çözümler üretmek }\end{array}$ & Tosun, 2009 \\
\hline & $\begin{array}{l}\text { İstihdam sorunları ve beslenme sorunlarının } \\
\text { çözümüne yönelik sosyal ve kültürel değerlere } \\
\text { sahip çıkılması }\end{array}$ & $\begin{array}{l}\text { Karakuzulu 2010; Özcan, 2016; Tosun, 2009; } \\
\text { İnceoğlu, } 2013\end{array}$ \\
\hline KÜLTÜREL YAPIYA DAIR & $\begin{array}{l}\text { Sosyo-kültürel değerlerin korunarak, toplumun } \\
\text { yerel kimliğinin göz önünde bulundurulup sahip } \\
\text { çıkıldığı yerel ürünler sistemi oluşturulması } \\
\text { amacı ile toplumun değerlerinin güvence altına } \\
\text { alınması }\end{array}$ & $\begin{array}{l}\text { Medved, 2016; Tuğun ve Karaman, 2014; } \\
\text { İnceoğlu, } 2013\end{array}$ \\
\hline
\end{tabular}


Sürdürülebilir kentleşme adına üzerinde durulan ve bu çalışmada sürdürülebilirlik kriterleri yukarıda değerlendirilen koşutlar temelinde mekânsal, ekonomik, kültürel, çevresel başlıklar üzerinden çalışma alanı Buldan için yaklaşımlar oluşturulması hedeflenmiştir.

\subsection{Yöntemin Açıklanması}

Araştırma sürdürülebilir kentleşmenin sağlanabilmesi için izlenmesi gerekli prensipleri ekolojik, mekânsal, ekonomik ve kültürel başlıklar olmak üzere dört başlıkta incelenmiştir. Bu noktada sürdürülebilirlik prensipleri literatürden gelen yaklaşımlarla alt başlıklar üzerinden değerlendirilip yeniden ele alınmıştır (Çizelge 2).

Çizelge 2. Sürdürülebilirlik modeli ve prensipleri

\begin{tabular}{|c|l|}
\hline \multicolumn{1}{|c|}{ YAKLAŞıMLAR } & \\
\hline \multicolumn{1}{|c|}{ ÇEVRESEL } & Poğal ekosistemin devamlıı̆ı̆ı ve biyolojik çeşitliliğin korunması \\
\hline & Tabii kaynak kullanımının desteklenmesi, Enerji tasarrufu sağlanması \\
\hline & Üretim ve tüketimde ekolojik ayak izinin en aza indirgenmesi \\
\hline & Atık-geri dönüşüm döngüsünün kurulması \\
\hline & Dengeli nüfus artışı \\
\hline MEKÂNSAL YAPIYA DAiR & Kontrollü arazi kullanımı \\
\hline & Sağlıklı ve güvenilir mekânların oluşturulması \\
\hline & $\begin{array}{l}\text { Ulaşımda ekolojik ayak izi düşürmek (bisiklet kullanımını artırmak, yürüme ve } \\
\text { toplu taşıma sistemi) }\end{array}$ \\
\hline & Koruma-kullanma dengesi sağlanması tarihsel kimliğin mekânda korunması \\
\hline EKONOMiK YAPIYA DAiR & Üretim ve tüketimde yeni teknolojik çözümler üretmek \\
\hline & Dengeli ekonomik büyümenin sağlanması \\
\hline KÜLTÜREL YAPIYA DAiR & Sosyo-kültürel değerlerin korunması \\
\hline & Yerel kimliğinin önceliğe alınması \\
\hline & Yerel ürünler sistemi oluşturulması \\
\hline & Kültürel ekosistemin devamlılığı \\
\hline &
\end{tabular}

Araştırma alanı Buldan yukarıda ortaya konulan sürdürülebilir kentleşme prensipleri üzerinden değerlendirilecektir. Bu noktada çalışma alanının mevcut durumunu tespit etmek önemlidir. Gerek alana dair ikincil ve üçüncül kaynaklardan elde edilen veriler, gerekse yerinde tespit ve gözlemlerden yararlanılarak yerleşmenin değerlendirilmesine yönelik potansiyel ve risk değerlendirmesi yapılacak, mekânsal, ekonomik, kültürel, ekolojik ve kurumsal yapı üzerinden Güçlü-Zayıf Yönler-FırsatlarTehditler (GZFT) analizi gerçekleştirilecektir. Saha çalışmaları boyunca elde edilen veriler eşliğinde, sorun ve riskler üzerinden mekânsal, ekonomik, sosyo-kültürel, çevresel bileşenlerine oturan sürdürülebilir kentleşme prensipleri üzerinden yaklaşım ve kararlar önerilecektir.

Araştırma, kırsal yerleşmelerin sahip olduğu ulusal ve uluslararası değerleri açısından sürdürülebilir kentleşme sağlanmasına yönelik politika ve stratejilerin geliştirilmesi, yeni modeller kurgulanması açısından önem taşımaktadır. Bu yönüyle, sürdürülebilir kentleşme üzerine yapılan tartışmalar, araştırmalar ve karar alıcılar tarafından kurgulanan planlama ve uygulama çalışmalarına yöntem tasarımı açısından katkı sağlayacağı düşünülmektedir.

\section{3. Çalışma Alanı}

Buldan İlçesi, Türkiye'nin Ege Bölgesi'nin güney kısmında yer alan Denizli ili'ne bağlı olup, kuzeyde Uşak ilii, batıda Manisa ve Aydın Illleri, kuzeyde ve doğuda Güney İlçesi, güneydoğuda Denizli-Merkez, güneyde ise Sarayköy İlçesi ile sınırlı olan Buldan İlçesi; Denizli Ili'nin 19 (on dokuz) ilçesinden biri olup il merkezine 47 km uzaklıktadır (Şekil 1). 

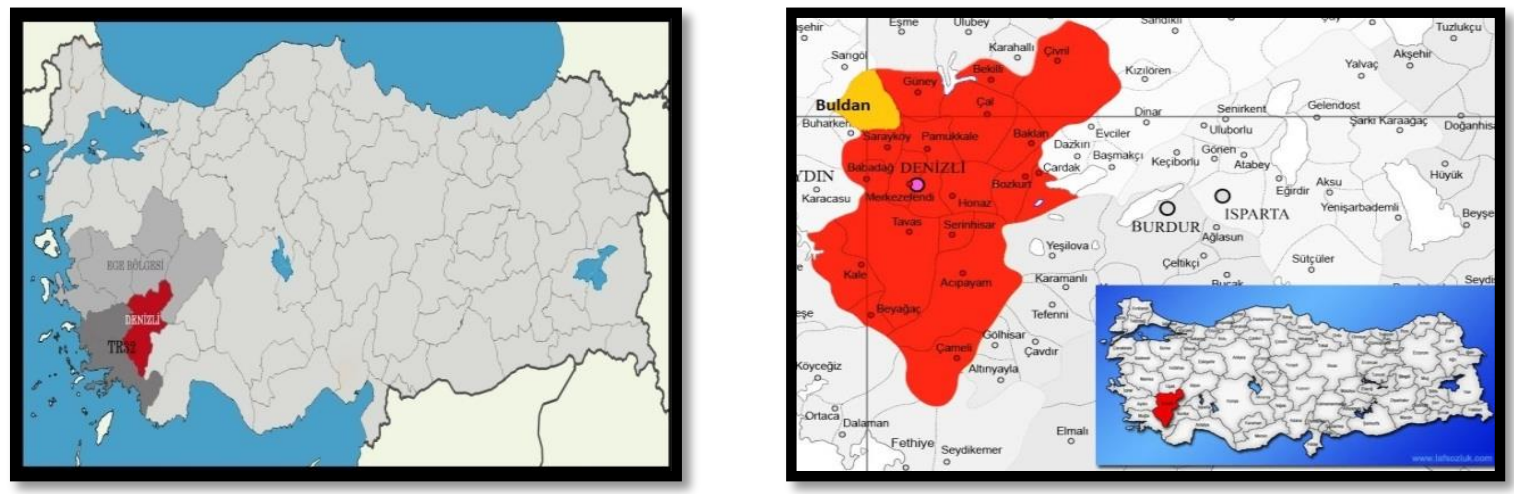

Şekil 1. Ülke ve kent içindeki konum

Çalışma alanı Buldan (Merkez) olup, 16.661 nüfuslu, yaklaşık 350 ha alanı kapsayan, kuzeyde geleneksel konut alanları (kentsel sit alanı), batıda Düzalan yerleşmesi, doğuda Cumhuriyet yerleşmesi ve güneyde ise Turan ve Karşıyaka yerleşmeleri ile çevrelenmiştir. Buldan Merkez'e ilk olarak 1579 yılında Güroluk Mahallesi ile yerleşme başlamış olup, kent gittikçe doğuya doğru bir yayılım göstermiştir. İlk yerleşmeler kentin batısında geleneksel konut dokusu olarak adlandırılan bölgede; ilçenin topografik olarak engebeli olmasından dolayı organik olarak gelişmiş, yapılaşma, sokak ve cadde oluşumları topografyaya göre şekillenmiştir. Kent günümüzde halk arasında "Eski Buldan" ve "Yeni Buldan" şeklinde ikiye ayrılmaktadır. Eski Buldan, geleneksel kent dokusunu içinde barındırırken, Yeni Buldan daha çok günümüz koşullarınca şekillenen yapılara ev sahipliği yapmaktadır ve Eski Buldan olarak nitelendirilen bölgede Buldan'ın yöresel mimarisini oluşturan Buldan evlerini görmek mümkündür.

Arazi çalışmalarından elde edilen verilere dayanarak; çalışma alanı \%28'i iyi bina niteliğine sahip, \%70'i 1-2 katlı, \%10'u ise 5 kat ve üstü yapılardan oluşan alan genellikle geleneksel kent dokusu ve çevresinin 1-2 katı konut alanları ile yoğunlaştığı alanlardır ve çalışma alanının \%55'i konut alanları ile çevrelenmiş bir bölge olarak tespit edilmiştir. Gözlemlenen çalışmalar kapsamında çalışma alanındaki geleneksel konut dokusu ve çevresinin genellikle 1-2 katlı yapılardan oluştuğu ve orta nitelikli bina niteliğine sahip konut alanlarından oluştuğu açıklanabilir (Şekil 2).

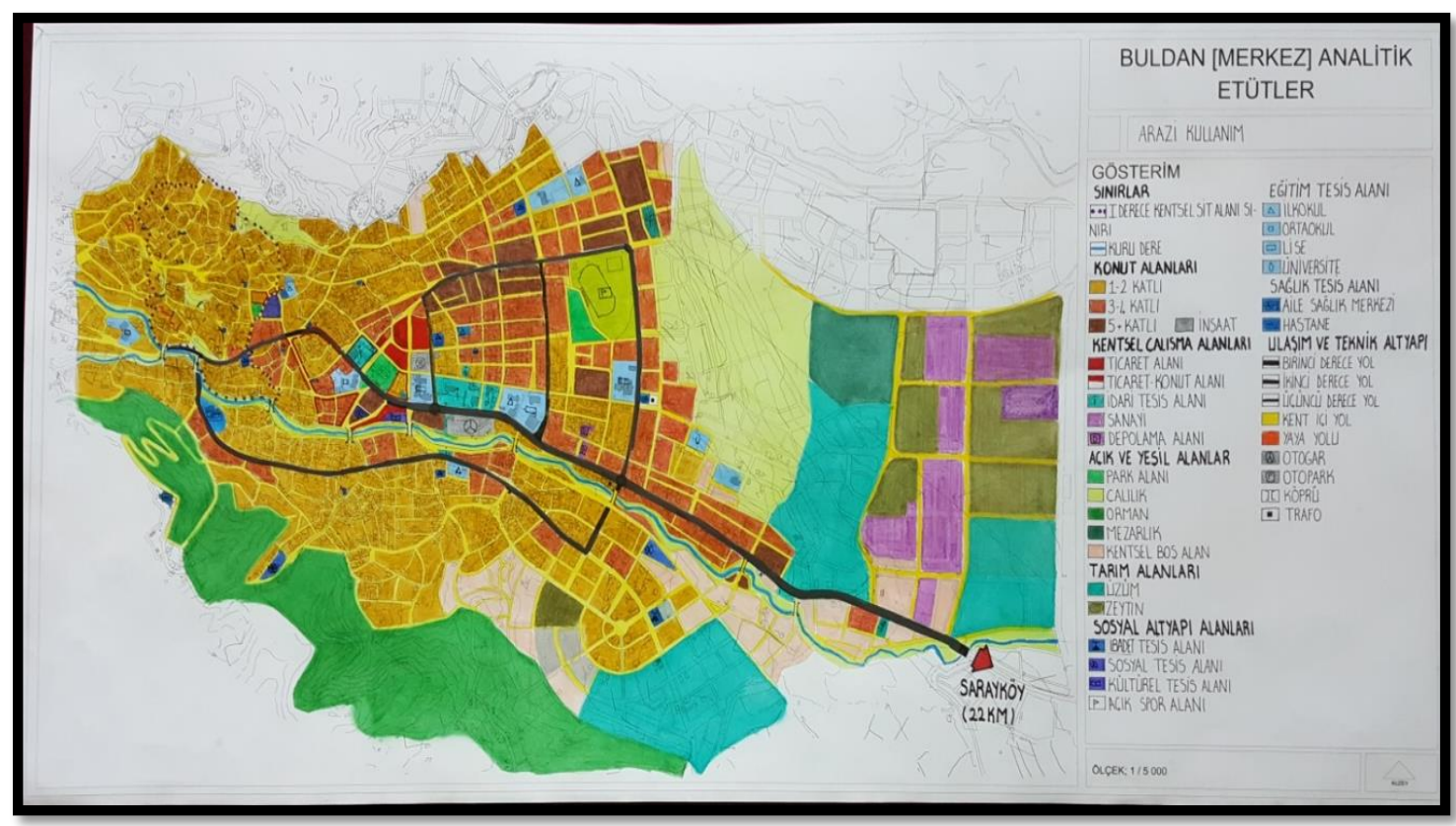

Şekil 2. Mevcut durum

Ulaşım ve teknik altyapı bakımından incelendiğinde; merkezin topografik olarak engebeli olmasından dolayı organik olarak gelişmiş, yapılaşma, sokak ve cadde oluşumları topografyaya göre şekillenmiştir. Topografyaya göre şekillenen sokak oluşumlarında kimilerinde merdivenler ile bağlanmıştır. 
Mevcut arazi kullanım dağııımı bakımından incelendiğinde; arazinin yaklaşık olarak \%55'ini yerleşim alanları oluşturmaktadır. Kentsel çalışma alanları yerleşmenin oluşturmakta \%5'ini ve yaklaşık \%11'lik dilimini ise tarım alanları izlemektedir (Tablo 3).

Çizelge 3. Mevcut arazi kullanım tablosu

\begin{tabular}{|c|c|c|c|c|}
\hline & & HA & M2 & $\%$ \\
\hline \multirow{2}{*}{$\begin{array}{l}\text { YERLEŞiM } \\
\text { ALANLARI }\end{array}$} & KONUT ALANI & 194.77 & 1947700 & 54.94 \\
\hline & INŞAAT ALANI & 1.7 & 17000 & 0.48 \\
\hline \multirow{4}{*}{$\begin{array}{l}\text { KENTSEL } \\
\text { ÇALIŞMA } \\
\text { ALANLARI }\end{array}$} & TICARET ALANI & 1.37 & 13700 & 0.39 \\
\hline & IDARI TESIS ALANI & 2 & 20000 & 0.56 \\
\hline & SANAYI & 12.5 & 125000 & 3.53 \\
\hline & DEPOLAMA & 0.16 & 1600 & 0.05 \\
\hline \multirow{5}{*}{$\begin{array}{l}\text { AÇIK VE YEŞiL } \\
\text { ALANLAR }\end{array}$} & PARK & 1.22 & 12200 & 0.34 \\
\hline & ÇALILIK & 30 & 300000 & 8.46 \\
\hline & ORMAN & 37.25 & 372500 & 10.51 \\
\hline & MEZARLIK & 7.6 & 76000 & 2.14 \\
\hline & KENTSEL BOŞ ALAN & 12.5 & 125000 & 3.53 \\
\hline \multirow{2}{*}{$\begin{array}{c}\text { TARIM } \\
\text { ALANLARI }\end{array}$} & ÜZÜM & 30 & 300000 & 8.46 \\
\hline & ZEYTIN & 10.5 & 105000 & 2.96 \\
\hline \multirow{5}{*}{$\begin{array}{c}\text { SOSYAL ALTYAPI } \\
\text { ALANI }\end{array}$} & IBADET TESIS ALANI & 0.74 & 7400 & 0.21 \\
\hline & SOSYO-KÜLTÜREL TESIS ALANI & 0.96 & 9600 & 0.27 \\
\hline & AÇIK SPOR ALANI & 3.39 & 33900 & 0.96 \\
\hline & SAĞLIK TESIS ALANI & 0.45 & 4500 & 0.13 \\
\hline & EĞiTiM TESIS ALANI & 3.91 & 39100 & 1.1 \\
\hline \multirow[t]{2}{*}{ TEKNIK ALTYAPI } & TEKNIK ALTYAPI & 3.51 & 35100 & 0.99 \\
\hline & TOPLAM ALAN & \multicolumn{3}{|l|}{351.02} \\
\hline
\end{tabular}

\section{Bulgular}

Yerleşmedeki çalışmalar kapsamında gerçekleştirilen yerinde gözlem ve arazi tespitleri ile mevcut durum elde edilmiştir. Mekânsal, ekonomik, sosyo-kültürel, ekolojik ve kurumsal yapı üzerinden GZFT analizi gerçekleştirilmiştir (Çizelge 4).

Çizelge 4. Buldan yerleşmesi GZFT analizi

\begin{tabular}{|c|c|c|c|c|}
\hline & GÜÇLÜ YÖNLER & ZAYIF YÖNLER & FIRSATLAR & TEHDITLER \\
\hline MEKÂNSAL YAPI & $\begin{array}{l}\text { 1.Farklı geleneksel } \\
\text { mimari dokuların } \\
\text { yanında, kentsel } \\
\text { imge haline gelen } \\
\text { Buldan evlerinin } \\
\text { varlığı } \\
\text { 2.Kent merkezinin } \\
\text { idari, ticari, tarihi } \\
\text { ve turizm merkezi } \\
\text { niteliğinin } \\
\text { yerleşime güçlü bir } \\
\text { kimlik } \\
\text { kazandırması } \\
\text { 3.Pamukkale'ye }\end{array}$ & $\begin{array}{l}\text { 1.Yerleşmelerin } \\
\text { altyapı ve ulaşım } \\
\text { hizmetlerinde } \\
\text { geri kalması } \\
\text { 2.Cazibe merkezi } \\
\text { niteliğine sahip } \\
\text { olabilecek } \\
\text { eğlence } \\
\text { alışveriş ve } \\
\text { noktalarının } \\
\text { eksikliği } \\
\text { 3.Kentte sağlık } \\
\text { odaklarının } \\
\text { yetersiz kalması }\end{array}$ & $\begin{array}{l}\text { 1.Tarihsel odak } \\
\text { niteliği ile } \\
\text { mekânsal işlevsel } \\
\text { açıdan } \\
\text { geliştirilebilir } \\
\text { turizm potansiyeli } \\
\text { 2.Buldan Meslek } \\
\text { Yüksek Okulu } \\
\text { (MYO)'nun } \\
\text { açılması ile MYo } \\
\text { ve çevresinde } \\
\text { ticaret alanlarının } \\
\text { saçaklanması } \\
\text { 3.Yerleşmede }\end{array}$ & $\begin{array}{l}\text { 1.Geleneksel doku } \\
\text { içerisinde } \\
\text { kullanılmayan } \\
\text { yapılardan oluşan } \\
\text { köhneme riski } \\
\text { 2.Kent için yapılan imar } \\
\text { planlarının bağ-bahçe } \\
\text { alanlarındaki } \\
\text { geleneksel doku ve } \\
\text { yaşamın göz ardı } \\
\text { edilerek, bu alanlarda } \\
\text { ifraza ve yüksek katlı } \\
\text { yapılara izin verilmesi } \\
\text { 3.Kentsel sit alanı ile }\end{array}$ \\
\hline
\end{tabular}




\begin{tabular}{|c|c|c|c|c|}
\hline & $\begin{array}{l}\text { olan yakınlığı ile } \\
\text { Tripolis-Hierapolis } \\
\text { arasında bağlantı } \\
\text { noktasının varlığı }\end{array}$ & $\begin{array}{l}\text { (Kişi başına düşen } \\
\text { yatak } \\
\text { sayısı:0.078) }\end{array}$ & $\begin{array}{l}\text { eğimli alan ve } \\
\text { dere yatağında } \\
\text { rekreasyon alan } \\
\text { potansiyeli içeren } \\
\text { yeşil alanların } \\
\text { varlığı }\end{array}$ & $\begin{array}{l}\text { yerleşim alanları } \\
\text { arasında geçiş bölgesi } \\
\text { olmamasından kaynaklı } \\
\text { siluetin bozulması }\end{array}$ \\
\hline EKONOMIK YAPI & $\begin{array}{l}\text { 1.Farklı turizm } \\
\text { pazarlarına yönelik } \\
\text { alternatif ürünlerin } \\
\text { varlığı } \\
\text { 2.Kentin } \\
\text { ekonomisinde yer } \\
\text { edinen Buldan } \\
\text { bezinin bilinirliği } \\
\text { 3.Turizme } \\
\text { yönlendirilecek } \\
\text { işgücünün varlığı }\end{array}$ & $\begin{array}{l}\text { 1.Kentin } \\
\text { ekonomisinde } \\
\text { devlet yardım ve } \\
\text { desteklerin } \\
\text { yetersizliği } \\
\text { 2.Sanayi ve tarım } \\
\text { sektörlerine } \\
\text { gerekli } \\
\text { desteklerin } \\
\text { verilmemesi } \\
\text { 3.Turizm } \\
\text { bilincinin } \\
\text { yeterince } \\
\text { gelişmemiş } \\
\text { olması }\end{array}$ & $\begin{array}{l}\text { 1.Pazarlama } \\
\text { konusunda ortak } \\
\text { hareket edilerek } \\
\text { kooperatifleşme } \\
\text { ve dernekleşme } \\
\text { potansiyeli } \\
\text { 2.Buldan bezinin } \\
\text { ekonomiye katkı } \\
\text { sağlayacak } \\
\text { geliştirilebilir } \\
\text { turizm } \\
\text { altyapısının varlığı } \\
\text { 3.Kentte üretilen } \\
\text { dokumaların } \\
\text { çeşitli fuarlarda } \\
\text { tanıtımının } \\
\text { sağlanması }\end{array}$ & $\begin{array}{l}\text { 1.Çevrede benzer } \\
\text { koşulları olan kent ve } \\
\text { ilçelerin Buldan'ın etki } \\
\text { çevresinde bulunan } \\
\text { turizm potansiyelini } \\
\text { kendi turizmlerine } \\
\text { katma isteği } \\
\text { 2.Kentte ev-atölye } \\
\text { birlikteliğinin } \\
\text { kaybolmaya } \\
\text { tutması yüz } \\
\text { 3.Yeterli tanıtım ve } \\
\text { pazarlama } \\
\text { faaliyetlerinin aktif ve } \\
\text { etkili olmaması }\end{array}$ \\
\hline $\begin{array}{c}\text { SOSYO- } \\
\text { KÜLTÜREL YAPI }\end{array}$ & 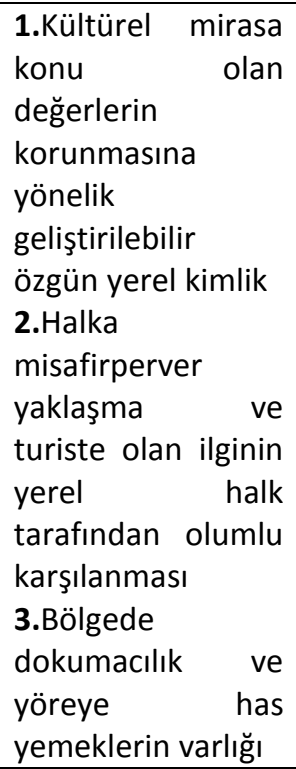 & $\begin{array}{l}\text { 1.Buldan kültürel } \\
\text { ve yerel kimlik } \\
\text { değerlerinin } \\
\text { koruması, } \\
\text { geliştirilmesi ve } \\
\text { tanıtımına } \\
\text { yönelik festival, } \\
\text { fuar vb. } \\
\text { etkinliklerin } \\
\text { yetersizliği } \\
\text { 2.Önemli pahip } \\
\text { potansiyele sahï } \\
\text { müze kültürünün } \\
\text { geliştirilememesi } \\
\text { 3.Yerel halkın } \\
\text { turistik tesisleri } \\
\text { yeterince } \\
\text { kullanmaması }\end{array}$ & 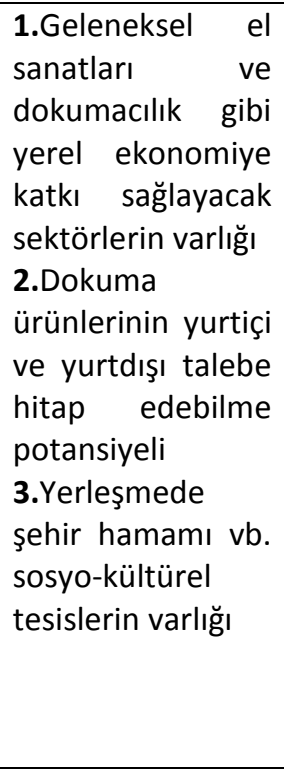 & $\begin{array}{lr}\text { 1.Sosyal } & \text { etkileşim } \\
\text { alanlarının } & \text { yetersizliği } \\
\text { nedeniyle } & \text { insan } \\
\text { ilişkilerinin } & \text { kentte } \\
\text { zayıflaması } & \\
\text { 2.Kentte } & \text { kültürel } \\
\text { merkezlerin } & \text { aktif } \\
\text { olmaması } & \\
\text { 3.İşgücünün } & \\
\text { azalmasıyla } & \text { beraber, } \\
\text { nüfusta dengesizliklerin } \\
\text { yaşanması }\end{array}$ \\
\hline EKOLOJIK YAPI & $\begin{array}{l}\text { 1.Alternatif turizm } \\
\text { türleri için } \\
\text { potansiyelin } \\
\text { yüksekliği } \\
\text { 2.Doğal sit alanı } \\
\text { olan Yayla Gölü ve } \\
\text { çevresinin birçok } \\
\text { canlıya yaşam } \\
\text { alanı sunması } \\
\text { 3.Doğal kaynak ve } \\
\text { değerlerin varlığı }\end{array}$ & $\begin{array}{l}\text { 1.Tarım } \\
\text { arazilerinin } \\
\text { parçalı ve küçük } \\
\text { olması ile düşük } \\
\text { verimli tarım } \\
\text { olması } \\
\text { 2.Yeraltı } \\
\text { kaynaklarının } \\
\text { büyük coğunluğunun } \\
\text { çorekli etütler } \\
\text { gereklimadığı için } \\
\text { yapılletilememesi } \\
\text { işlemen alan } \\
\text { 3.Yeşil kullanımlarının } \\
\text { sürekliliğinin } \\
\text { sağlanamaması } \\
\text { ve yetersizliği }\end{array}$ & $\begin{array}{l}\text { 1. İsletilebilir } \\
\text { termal } \\
\text { kaynakların varlığı } \\
\text { 2.Doğal } \\
\text { kaynakların } \\
\text { sürdürülebilirliği } \\
\text { 3.Dere yatağı ve } \\
\text { çevresinde } \\
\text { rekreasyonel alan } \\
\text { potansiyeli }\end{array}$ & $\begin{array}{lr}\text { 1.Sanayi } & \text { alanlarının } \\
\text { gelişerek, doğal kaynak } \\
\text { alanları üzerinde baskı } \\
\text { oluşturması } \\
\text { 2.Turizm } & \\
\text { dayalı sektörüne } & \text { ekonominin } \\
\text { tarımsal } & \text { faaliyetleri } \\
\text { kısıtlaması } & \\
\text { 3.Doğa } & \text { koruma } \\
\text { bilincinin } & \text { gelişmemiş } \\
\text { olması } & \end{array}$ \\
\hline
\end{tabular}




\begin{tabular}{|c|c|c|c|c|}
\hline KURUMSAL YAPI & $\begin{array}{l}\text { 1.Dokumacılı } \\
\text { sektörünü } \\
\text { destekleyecek } \\
\text { kooperatif, esnaf } \\
\text { odaları ve } \\
\text { dokumacı } \\
\text { birliklerinin } \\
\text { bulunması } \\
\text { 2.Ülke, il ve ilçe } \\
\text { bazında stratejik } \\
\text { planların } \\
\text { hazırlanması } \\
\text { 3.Yerleşmede } \\
\text { bulunan sit alanları } \\
\text { sayesinde katılımcı } \\
\text { ve paydaşların } \\
\text { bulunması }\end{array}$ & $\begin{array}{l}\text { 1.Finansman ile } \\
\text { ilgili sorunlar ve } \\
\text { işletmelerin küçük } \\
\text { olmasından, } \\
\text { yatırımların da } \\
\text { küçük olması } \\
\text { 2.Yerleşmede } \\
\text { yapılan proje ve } \\
\text { yatırımların } \\
\text { olması az } \\
\text { 3.Turizm altyapısı } \\
\text { ve arkeolojik } \\
\text { kazıların } \\
\text { hızlandırılması için } \\
\text { kamu } \\
\text { kaynaklarında } \\
\text { zorluk yaşanması }\end{array}$ & $\begin{array}{l}\text { 1.Turizm tanıtım } \\
\text { ve eğitim } \\
\text { faaliyetlerinde } \\
\text { derneklerin rol } \\
\text { alma potansiyeli } \\
\text { 2.Toplum } \\
\text { yararına çalışan } \\
\text { kurum ve } \\
\text { derneklerin } \\
\text { bulunması } \\
\text { 3.Belediyenin } \\
\text { turizm konusunda } \\
\text { yapılacak } \\
\text { çalışmalara } \\
\text { önderlik } \\
\text { potansiyeli etme }\end{array}$ & $\begin{array}{l}\text { 1.Konaklamanın çok } \\
\text { kısıtlı sayıda olması } \\
\text { vb. hizmetlerde } \\
\text { farklılaşmanın } \\
\text { bulunmaması } \\
\text { 2.Ortak çalışma } \\
\text { bilincinin paydaşlar } \\
\text { arasında gelişmemiş } \\
\text { olması } \\
\text { 3.Siyasal } \\
\text { ekonomik } \\
\text { istikrarsızlıklar }\end{array}$ \\
\hline
\end{tabular}

GZFT analizlerinden özetle; aile ölçeğinde ve geleneksel tarzdaki dokumacılığın kaybolma eğiliminde olması, ticarete ve turizme dönük işlevlerin kısıtlı kalması dolayısıyla işgücünün azalmasıyla birlikte, beraberinde getirdiği nüfusta dengesizlikler tespit edilmesi ve sosyal etkileşim alanlarının yetersizliği, yerli halkın turistik tesisleri yeterince kullanmaması sonucu yere özgü değerlerin işlevini yitirmesi söz konusudur. Konaklama alanlarının kısıtlı sayıda bulunması ve hizmetlerde farklılaşmanın olmamasından kaynaklı tesis yapılanmasında sıkıntıların bulunması, yerleşmede sağlık odağının eksik kalması ile kişi başına düşen yatak sayısının 0.078 olduğu tespit edilmiş ve sosyo- kültürel kent yaşamının zayıf kalması, yerel halkın mevcut turistik tesisleri yeterince kullanmamasından kaynaklı sosyo-kültürel kent yaşamı zayıf kalmıştır.

Çalışma alanındaki gözlem ve tespitlere dayalı olarak belirlenen riskler şunlardır;

\section{Sorunlar ve Riskler;}

1. Kentte geçmişte ev tipi atölyeler Buldan genelinde yaygın olarak görülse de günümüzde bu durum azalmış, kendini fabrika tipi işyerlerinde çalışmaya bırakmıştır.

2. Ticaret ve turizm ağırlıklı sektörel stratejilerin mekânsal altyapılar ile desteklenmemesi durumunda yöre halkının var olan sosyal-kültürel ve teknik altyapı (sosyal donanımlar ve ulaşılabilirlik) yoksunluğunun hızla artmasına neden olacaktır.

3. Kentin ekonomisinde önemli yer edinen Buldan dokumalarının günümüzden önce de küçük hacimde üretim yapan ve makinelerden yararlanmayan ve geleneksel dokumacılığın gerilemeye yüz tutmuş olması nedeniyle bu üretim biçiminin de hızla kaybolmaya başlaması ve iş imkânlarının azalması ile beraber istihdam sorunlarının çıkması ve göç olgusunun ortaya çıkması.

Yerleşmeye ilişkin yorumlanan veriler ışığında; dokumacılık artık kendini elektrikli makinelerden yararlanan, el iş̧̧iliğinin değer kaybettiği çalışmaya bırakmıştır. Mevcut durumun getirdiği problemler karşısında yerleşmenin merkez bölgesinden uzaklaştıkça niteliksiz ve güvenlik sıkıntısının olduğu alanlar oluşmuştur. Geleneksel doku içerisinde ise kullanılmayan yapılarda köhneme riski bulunmaktadır ve yerleşmenin kuzeyinde konut bölgesine yakın olan alanda heyelan riski tespit edilmiştir (Şekil 3). 


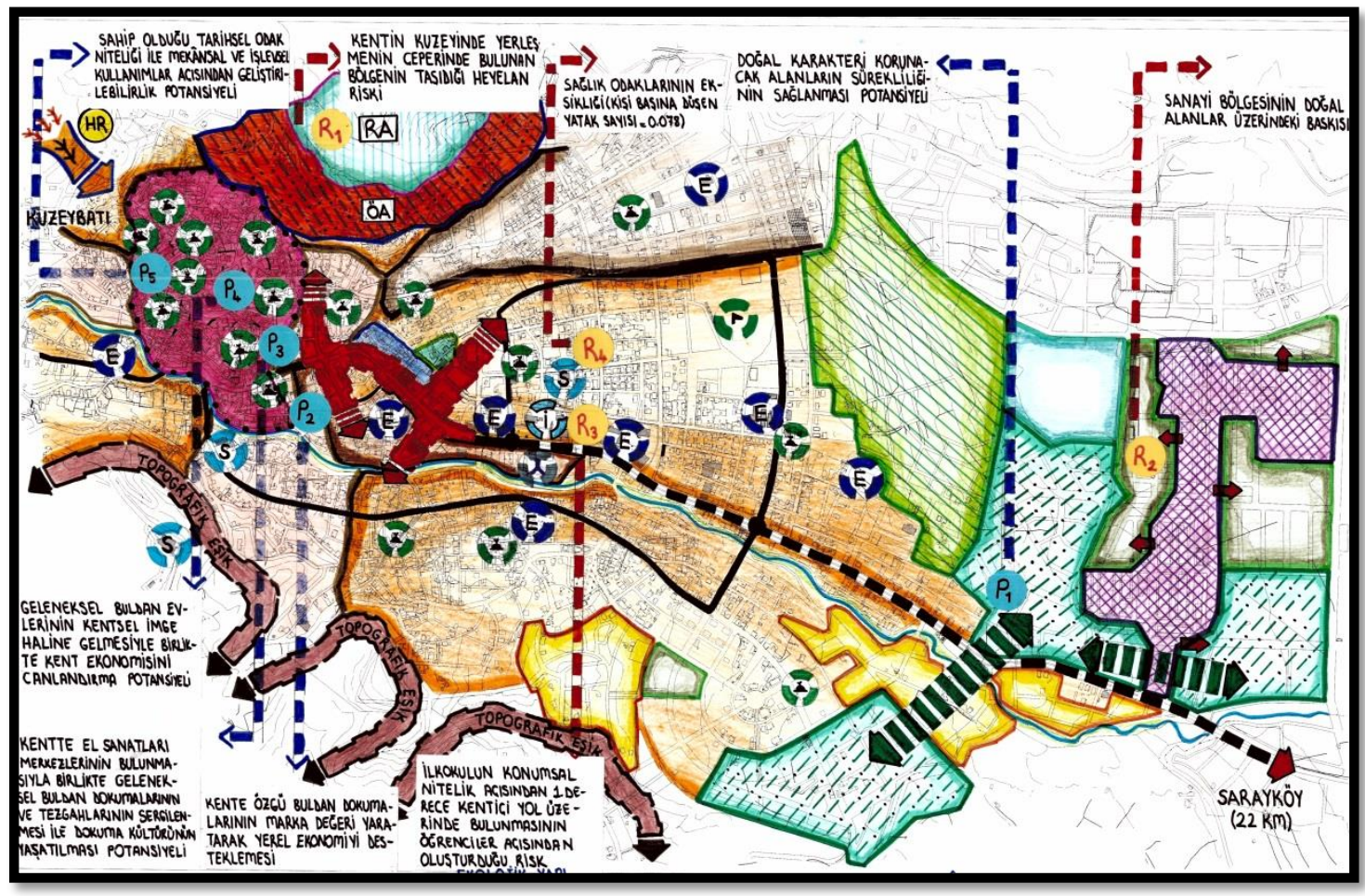

Şekil 3. Bütünleşik sentez

Çalışma alanındaki tespit ve gözlemlere dayalı olarak tarihsel odak niteliği bulunan yerleşmede, kültürel mirasa konu olan değerlerin sahip çıkılması doğrultusunda özgün yerel kimliğin korunması ile geliştirilebilir turizm potansiyeline sahip olması, Pamukkale'ye olan yakınlığı ve farklı turizm pazarlarına yönelik alternatif ürün varlığına sahip olması güçlü bir potansiyel olup, yerleşme için önem taşımaktadır.

\section{Değerlendirme ve Tartışma}

Bu çalışmada sürdürülebilir şehirleşme kriterleri bağlamında öncelikle Mekânsal Planlar Yapım Yönetmeliği kapsamında Genel Planlama Esasları başlığı altında Madde-7'de $f$ bendinde yer alan "Doğal, tarihi ve kültürel değerlerinin koruma ve kullanma dengesinin sağlanması" esası doğrultusunda Buldan yerleşmesinde elde edilen analiz çalışmaları ile kültürel ve doğal miras değerlerinden oluşan mekânsal ve işlevsel kurgusuna ilişkin sürdürülebilir kentleşmenin sağlanması için oluşturulan çalışmalar bütününde bazı stratejiler ortaya konulmuştur (Tablo 5).

Çizelge 5. Sürdürülebilirlik prensipleri ve Buldan sürdürülebilirlik modeli

\begin{tabular}{|c|c|c|}
\hline YAKLAŞIMLAR & PRENSIPLER & BULDAN YERLEŞIMi içiN STRATEJILER \\
\hline \multirow{5}{*}{ ÇEVRESEL } & $\begin{array}{l}\text { Doğal ekosistemin devamlılığı ve biyolojik } \\
\text { çeşitliliğin korunması }\end{array}$ & $\begin{array}{l}\text { Doğal karakteri korunacak alanların } \\
\text { sürekliliğinin sağlanması }\end{array}$ \\
\hline & $\begin{array}{l}\text { Tabii kaynak kullanımının desteklenmesi, } \\
\text { Enerji tasarrufu sağlanması }\end{array}$ & $\begin{array}{l}\text { Mevcut enerji kaynaklarına yönelme } \\
\text { Tüketimin azaltılması }\end{array}$ \\
\hline & $\begin{array}{l}\text { Üretim ve tüketimde ekolojik ayak izinin en } \\
\text { aza indirgenmesi }\end{array}$ & $\begin{array}{l}\text { Arazi kulllanım kararlarında bütüncül } \\
\text { yaklaşımlar } \\
\text { Üretim teknolojisinde yeni nesil araçlar }\end{array}$ \\
\hline & Atık-geri dönüşüm döngüsünün kurulması & $\begin{array}{l}\text { Geri dönüşüm politika ve kararları yerel } \\
\text { yönetim tarafından ortaya konmalıdır. }\end{array}$ \\
\hline & Dengeli nüfus artışı & Nüfus projeksiyonlarının gerçekleştirilmesi \\
\hline \multirow{4}{*}{$\begin{array}{l}\text { MEKÂNSAL YAPIYA } \\
\text { DAIR }\end{array}$} & Kontrollü arazi kullanımı & \multirow{2}{*}{$\begin{array}{l}\text { Arazi kulllanım kararlarında bütüncül } \\
\text { yaklaşımlar }\end{array}$} \\
\hline & $\begin{array}{l}\text { Sağlıklı ve güvenilir mekânların } \\
\text { oluşturulması }\end{array}$ & \\
\hline & Ulaşımda ekolojik ayak izi düşürmek & $\begin{array}{l}\text { Bisiklet kullanımını artırmak, yürüme ve toplu } \\
\text { taşıma sistemleri oluşturmak } \\
\text { Ulaşım hiyerarşisi kurmak }\end{array}$ \\
\hline & Koruma-kullanma dengesi sağlanması & Kültürel birikimine dayanan mekânsal ve \\
\hline
\end{tabular}




\begin{tabular}{|c|c|c|}
\hline & tarihsel kimliğin mekânda korunması & işlevsel kullanımların geliştirilmesi \\
\hline \multirow{3}{*}{$\begin{array}{l}\text { EKONOMIK YAPIYA } \\
\text { DAIR }\end{array}$} & $\begin{array}{l}\text { Üretim ve tüketimde yeni teknolojik } \\
\text { çözümler üretmek }\end{array}$ & Yeni nesil teknolojiler ve sistemlerin takibi \\
\hline & \multirow[t]{2}{*}{ Dengeli ekonomik büyümenin sağlanması } & $\begin{array}{l}\text { Ziyaretçi sayısının artırıması ile kent } \\
\text { ekonomisine katkı sağlanması }\end{array}$ \\
\hline & & Buldan dokumalarının marka değeri yaratılması \\
\hline \multirow{4}{*}{$\begin{array}{c}\text { KÜLTÜREL YAPIYA } \\
\text { DAIR }\end{array}$} & Sosyo-kültürel değerlerin korunması & $\begin{array}{l}\text { Dokumacılığın aile ölçeğinde ve geleneksel } \\
\text { tarzda sürdürülmesinin desteklenmesi }\end{array}$ \\
\hline & Yerel kimliğinin önceliğe alınması & $\begin{array}{l}\text { Geleneksel Buldan evlerinin kentsel imge } \\
\text { haline getirilmesi }\end{array}$ \\
\hline & Yerel ürünler sistemi oluşturulması & $\begin{array}{l}\text { - Dokumaya özgü el sanatları merkezlerinin } \\
\text { kurulması } \\
\text { - Yerleşime özgü ürünlerin (bağcılık, meyvecilik } \\
\text { vb.) yetiştirilmesi mekânsal alanların } \\
\text { korunması ve yeni alanların oluşturulması. }\end{array}$ \\
\hline & Kültürel ekosistemin devamlılığı & $\begin{array}{l}\text { Dokuma kültürünün sürdürülebilirliğinin ve } \\
\text { korunmasının sağlanması }\end{array}$ \\
\hline
\end{tabular}

Kentin tarihsel bilgileri eşliğinde, çevresel kaynak ve kültürel miras değerlerinin biçimlendirdiği mekânsal karakteristik ve işlevsel kimlik değerlerinin oluşturduğu özgün yerel kimliğin korunması ve sürdürülebilir kentleşmenin sağlanması adına mekânsal, ekonomik, sosyo-kültürel, ekolojik ve bileşenler çerçevesinde Buldan yerleşkesi için politika ve stratejiler geliştirilmiştir. Modele göre özetle sürdürülebilir bir Buldan yerleşmesi için;

1. Geleneksel Buldan evlerinin kentsel imge haline getirilmesi ve ziyaretçi sayısının artırılması ile kent ekonomisine katkı sağlanması

2. Yerleşmede dokumaya özgü el sanatları merkezlerinin kurulması, geleneksel Buldan dokumalarının ve tezgâhlarının sergilenmesi ile yöreye özgü dokuma kültürünün sürdürülebilirliğinin ve korunmasının sağlanması

3. Özgün Buldan dokumalarının marka değeri yaratılması ve yerel ekonomiyi desteklemesi

4. Tarihsel arka planı ve kültürel birikimine dayanan mekânsal ve işlevsel kullanımların geliştirilmesi

5. Doğal karakteri korunacak alanların (bağ-bahçe-ağaçlık) sürekliliğinin sağlanması

6. Yerleşime özgü ürünlerin (bağcılık, meyvecilik vb.) yetiştirilmesi için uygun alanların korunması ve yeni alanların oluşturulması gereklidir.

Yerleşmede kentsel sit alanının korunduğu, yere özgü kimliğin korunması amaçlı orta yoğunluklu gelişme konut alanları önerilerek dengeli bir nüfus artışının sağlanması adına Lineer projeksiyon yöntemi kullanılmış olup 2040 yılı nüfusu 21.000 olarak öngörülmüştür (Çizelge 6).

Çizelge 6. Buldan (2040 Yılı) Lineer Nüfus Projeksiyonu

\begin{tabular}{|c|c|c|c|c|c|}
\hline \multicolumn{7}{|c|}{ Projeksiyon Yılları } \\
\hline $\mathbf{2 0 1 5}$ & $\mathbf{2 0 2 0}$ & $\mathbf{2 0 2 5}$ & $\mathbf{2 0 3 0}$ & $\mathbf{2 0 3 5}$ & $\mathbf{2 0 4 0}$ \\
\hline 16429 & 17462 & 18495 & 19528 & 20560 & 21593 \\
\hline
\end{tabular}

Kontrollü arazi kullanımı ile dengeli ekonomik büyümenin sağlanması adına kaynakların etkin ve verimli kullanılarak yoksulluğun giderilmesi çerçevesinde kent merkezi ve yakın çevresindeki konut bölgeleri yüksek yoğunluklu konut bölgesi olup yerleşmenin çeperine doğru gidildikçe düşük yoğunluklu konut bölgeleri olarak önerilmiştir. 2040 yılındaki nüfus projeksiyonu hesaplamalarına göre, yaklaşık 29 ha alana sahip K1 bölgesinde 4935 kişi yaşaması öngörülmüş olup yoğunluğu 130180 ki/ha arasındadır. Yaklaşık 18 ha alana sahip K2 bölgesinde 1800 kişi yaşaması öngörülmüş olup yoğunluğu 85-110 ki/ha arasında olmaktadır. Yaklaşık 26 ha alana sahip GB1 bölgesinde 2124 kişi yaşaması öngörülerek yoğunluğu 65-85 ki/ha arasındadır. Yaklaşık 27 ha alana sahip GD1 bölgesinde ise 3312 kişi yaşaması öngörülmüş olup yoğunluğu 110-130 ki/ha arasındadır. Yaklaşık 50 ha alana sahip G1 bölgesinde de 6138 kişi yaşaması öngörülmüş olup yoğunluğu 110-130 ki/ha arasındadır (Şekil 4). 


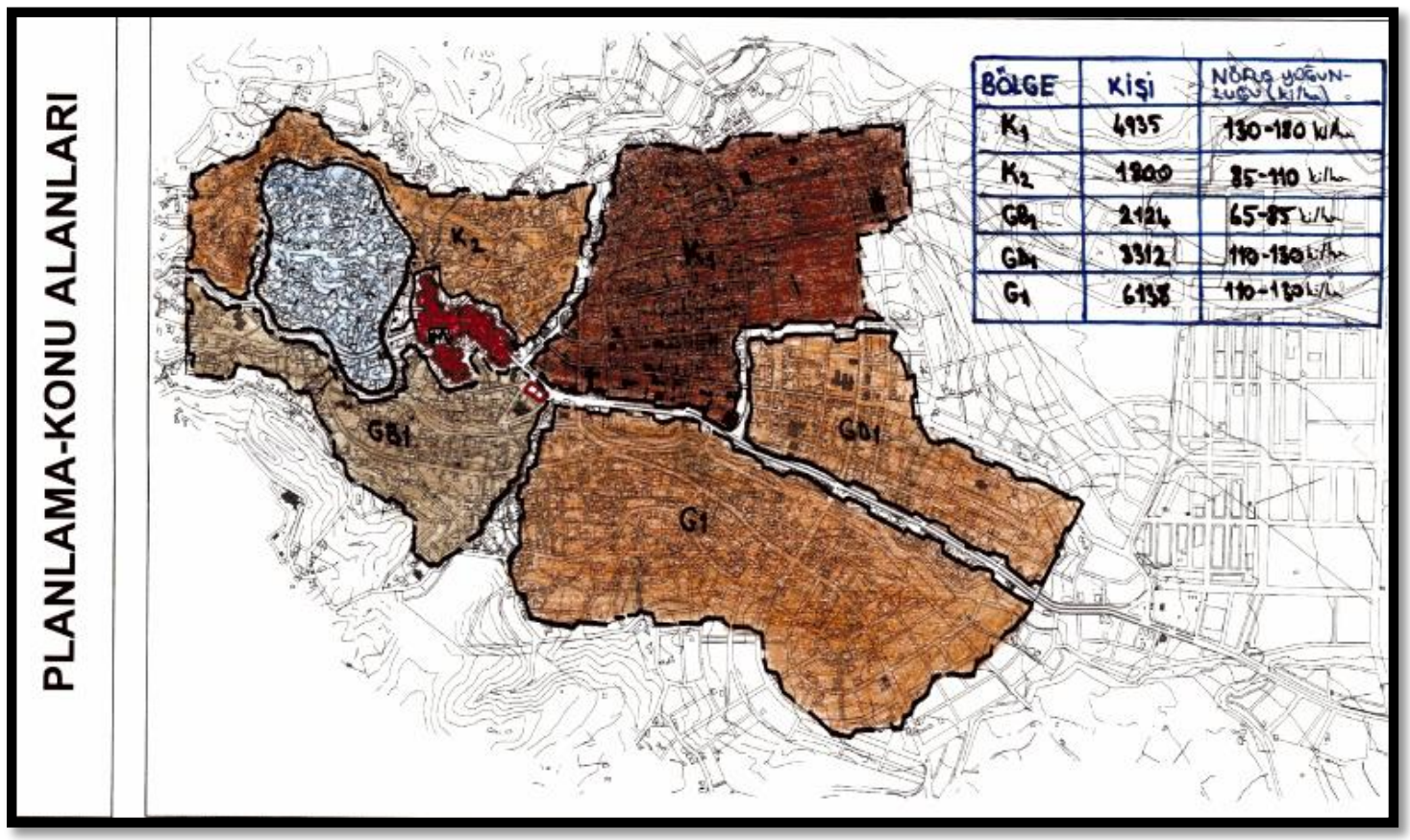

Şekil 4: Buldan'da önerilen nüfus bölgelemeleri yoğunlukları

Yerleşme için ortaya konan stratejilerin gerçekleşmesi amacı ile doğal çevrenin korunması önceliği ele alınarak yenileme müdahale çalışmaları ile sokak sağlıklaştırma, çevre sağlıklaştırma, kentsel tasarım projeleri ve peyzaj ögelerinin de sosyo-kültürel yaşantının yükseltilmesi hedefi bağlamında müdahale yöntemleri çevresi ile beraber bütüncül bir kapsamda ele alınmış, öncelikli müdahale konuları ortaya konmuştur. Yerleşimin merkezinde, merkez yenileme canlandırma müdahale konusu başlığı altında ve ayrıntıda kentsel tasarım ilkelerinin yer aldığı tasarım çalışmaları uygulanacaktır (Çizelge 7).

Çizelge 7. Öncelikli Müdahale Konu ve Alanları

\begin{tabular}{|c|c|c|}
\hline MÜDAHALE ALANLARI & MÜDAHALE KONUSU & MÜDAHALE YÖNTEMLERI \\
\hline Kent Merkezi ve Yakın Çevresi & Merkez Yenileme Canlandırma & $\begin{aligned}> & \text { Kentsel Tasarım } \\
& \text { Projeleri } \\
> & \text { Peyzaj Ögeleri } \\
> & \text { Çevre Düzenleme } \\
& \text { Projeleri } \\
> & \text { Sokak Sağlıklaştırma }\end{aligned}$ \\
\hline Gölbaşı ve Yakın Çevresi & Yenileme & $\begin{array}{ll}> & \text { Peyzaj Ögeleri ve } \\
& \text { Projeleri } \\
> & \text { Çevre Düzenleme } \\
& \text { Projeleri } \\
> & \text { Kentsel Tasarım } \\
& \text { Projeleri } \\
\end{array}$ \\
\hline $\begin{array}{l}\text { Cumhuriyet Yerleşmesi ve } \\
\text { Yakın Çevresi }\end{array}$ & Yenileme & $\begin{array}{ll} & \text { Sokak Sağlıklaştırma } \\
>\quad & \text { Çevre Sağlıklaştırma }\end{array}$ \\
\hline $\begin{array}{l}\text { Turan Yerleşmesi ve Yakın } \\
\text { Çevresi }\end{array}$ & Yenileme & $\begin{array}{l}>\text { Sokak Sağı̆ıklaştırma } \\
>\text { Çevre Sağlıklaştırma }\end{array}$ \\
\hline
\end{tabular}

Yukarıda sayılan öneriler doğrultusunda, etkileşim uyum fonksiyonu gözetilerek, ticarete ve turizme dönük işlevlerin yöresel ürünler ile buluştuğu, yerleşimin yöreye özgü ürünlerinin, kentin şimdiye kadar var olan kimliğini kaybetmemesi adına detayda mekânsal plan kararları getirilmiştir. Bu çerçevede Dokuma müzesi ve el sanatları merkezleri arasında bağlantı aksı oluşturularak, yerleşmenin merkezi ve geleneksel doku arasındaki bölgede yer alan dokuma müzesi sayesinde dokumanın üretildiği gerçek üretim mekânının uygulamalı, eğitici ve dokumacılığın hikayesini 
anlatacak değerler ve bilgiler eşliğinde gerçekleştirildiği, sosyal donatı alanları ile bütünlük sağlandığı, makine üretiminden çok geleneksel dokumacılı̆̆ın devam ettirilmesine yönelik bir işlevsel kimlik önerisi getirilmiştir. Yerleşmedeki üniversite ve dokuma tekstil atölyelerinin varlığı korunmuş ve iş birliği ile hem kentin gelişme sürecinde ekonomik kalkınmaya yarar sağlayacak dokuma ürünlerinin sürdürülebilirliğinin sağlanması, hem de gelişen, yenilenen eğitim süreçleri ile deneyimlenmesi sonucu yörenin değerlerini geleceğe dönük korunması bakımından katkı sağlayacağı öngörülmüştür (Şekil 5).

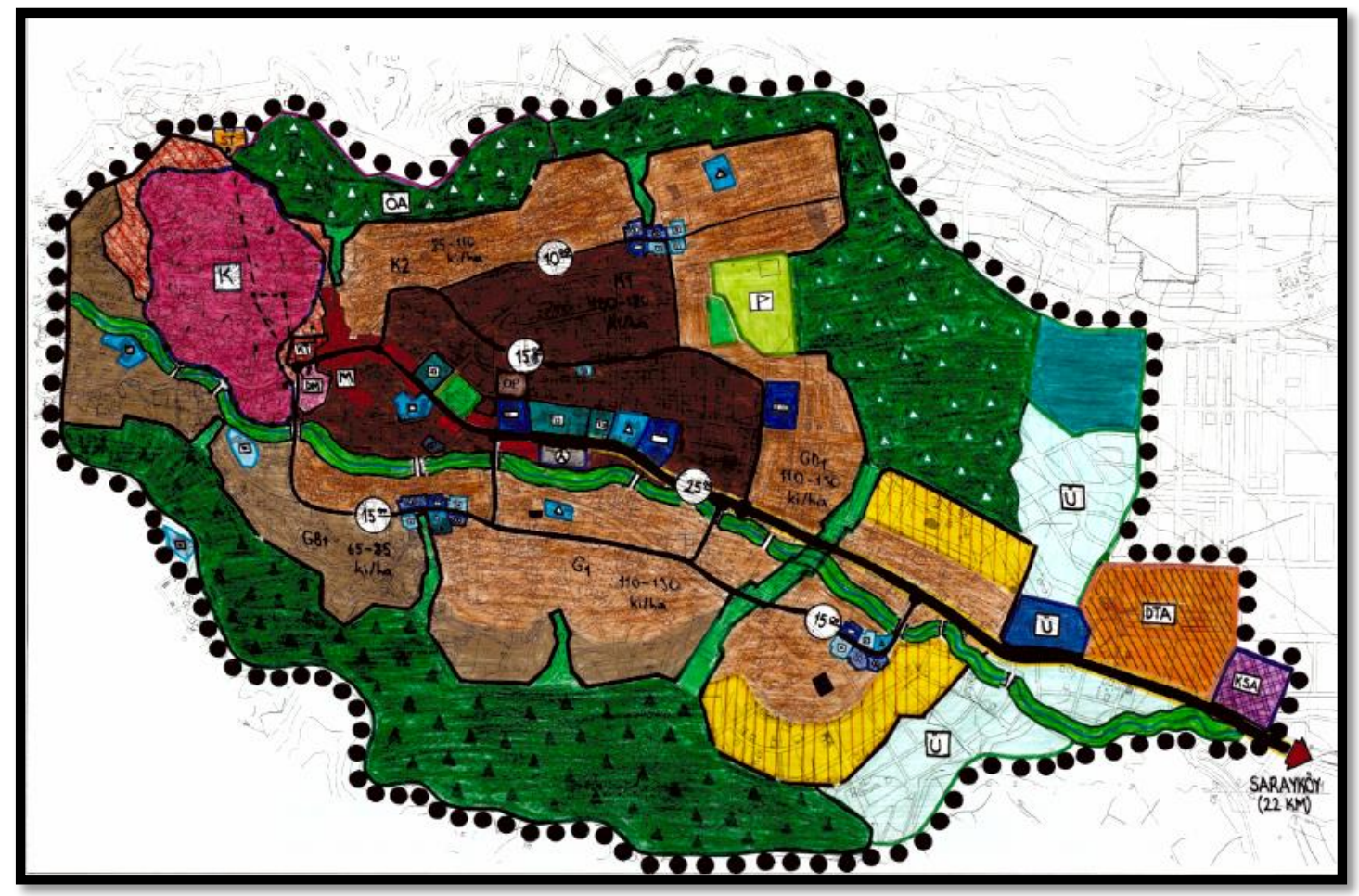

Şekil 5. Buldan (Merkez) ilkesel strateji planı-nazım imar planı

Yerleşmede mevcutta da Atatürk Caddesi olarak geçen, kentin ana aksını oluşturan ve bir meydan ile kente bağlanan cadde kentin birinci derece yolu olup, yirmi beş (25) metre olarak önerilmiş ve bu yollara bağlanan yollar on beş (15) metrelik olarak kentin ikinci derece yolları olması hedeflenmiş, bütün ulaşım arterlerinde bisiklet yolu ayrılmıştır. Kentin kuzeydoğusunda ikinci derece yola bağlanan yol ise on (10) metrelik olarak önerilmiş olup üçüncü derece kent içi yol olması öngörülmüştür. Yerleşmede ilk müdahale alanı olarak merkez ve yakın çevresinin seçilmesinin nedeni; yerleşmenin iş kısımlarına olumlu etki yapacağı düşünülmüş olup yenileme, koruma ve canlandırma çalışmalarında projede uygulama amaçlı öncelikle etaplama çalışması yapılmıştır. İkinci müdahale alanı olarak yerleşmenin güneydoğusunda bulunan mevcutta diğer yerleşim alanlarına göre farklı doku niteliğine sahip olan Gölbaşı ve çevresi seçilmiştir. Kuru dere ve çevresinde ekolojik koridor oluşturulması hedeflenmiştir. Bölgede gerekli alanlarda peyzaj ögeleri ve projeleriyle desteklenerek, çevre düzenleme projeleri ve kentsel tasarım projeleriyle yerleşmede gerekli düzenlemelerin yapılması sağlanacaktır. Kent merkezine erişilebilirlik açısından uzak mesafede bulunan Gölbaşı yerleşmesi, ihtiyacı olan bütün donatı ihtiyaçlarını kendi içerisinde karşılayacak şekilde planlanması hedeflenmiştir. Sosyo-kültürel kalitenin en refah düzeye ulaştırılması amacıyla yerleşmedeki alanlar kentsel projelerle desteklenecek ve doğal çevrenin korunması önceliği ele alınarak sokak sağlıklaştırma ve yenileme çalışmaları yapılacaktır. Üçüncü müdahale alanı olarak ise yerleşmenin kuzeydoğu bölgesi olan Cumhuriyet yerleşmesi ve çevresi seçilmiştir. Üniversitenin yakınında 1. derece kentiçi yol üzerindeki alanda ise üst ölçekli plan kararlarından alınan bölgenin de planda, gelişme konut bölgesi olarak planlanmıştır. Burada gerekli nüfusa hitap edecek şekilde ünitenin sosyo-kültürel seviyesini refah düzeye ulaştırılması amacıyla yerleşmenin ihtiyaçlarını karşılayacak kadar donatı alanları planlanmış olup doğal çevrenin korunması önceliği ele alınarak sokak 
sağılıklaştırma ve yenileme çalışmaları yapılacaktır. Dördüncü müdahale alanı olarak da Turan yerleşmesi ve yakın çevresi ele alınmıştır.

Yerleşmede bulunan göğüs hastalıkları hastanesinin ormanlık alanda bulunmasıyla kentin uğrak yeri olması özelliğinin artırılarak hastanedeki yatak kapasitesinin de gerekli nüfusa hitap edecek şekilde düzenlenmesi planlanmıştır. Yerleşmedeki alanlar kentsel projelerle desteklenecek ve doğal çevrenin korunması önceliği ele alınarak sokak sağlıklaştırma ve yenileme çalışmaları yapılacak olup kuru dere yatağının rekreasyonel kullanımlar ile desteklendiği ekolojik koridor bu bölgede de devam edecektir (Şekil 6). Yerleşmenin kuzeyinde, konut alanlarının çeperinde tespit edilen, heyelan riski bulunan alan önlemli alan olarak ele alınıp, ağaçlandırılacak alanlar olarak karar verilmiştir. Yerleşmeyi ikiye ayıran kuru dere ve çevresinin rekreasyonel kullanımlar içeren ekolojik koridor oluşturulması amaç edinilmiş olup, yerleşmenin kuzeyinde kenti seyir imkânı sunabilecek uygun arazi yapısının varlığı ile vista noktaları önerilmiştir.
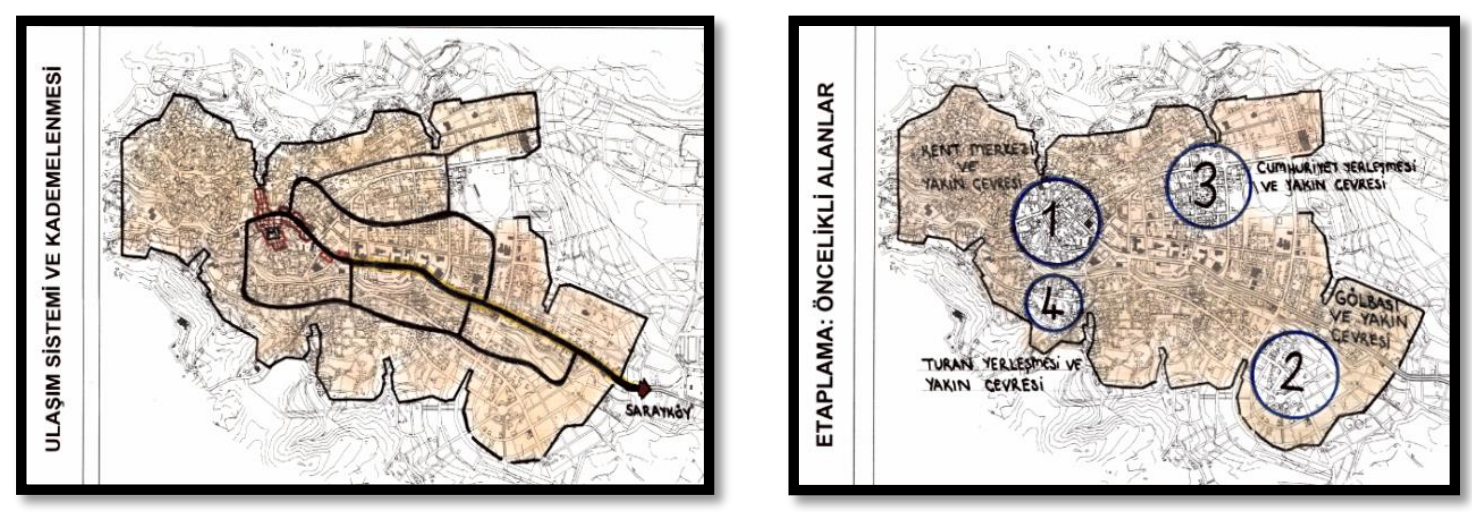

Şekil 6: Buldan'da önerilen ulaşım sistemi kademelenmesi ve etaplamada öncelikli alanlar

Konaklama alanlarının kısıtlı sayıda bulunması ve hizmetlerde farklılaşmanın olmamasından kaynaklı tesis yapılanmasında sıkıntılar yaşanması, yerleşmede sosyo-kültürel yaşam kalitesinin sürdürülmesi adına nitelikli ve güvenilir mekânların bulunmaması, doğal ve kültürel miras değerlerinin gelecek kuşaklara aktarılması adına düzenlemelerin bulunmaması, yerleşmenin yere özgü değerlerini kaybetmesine neden olacaktır. Yerleşmede ekonomik kalkınmaya büyük getiri sağlayacak geleneksel dokuma kültürünün devam ettirilmesi sağlandığında ve yöredeki doğal ve kültürel miras değerleri ve yöreye has yemek kültürü devam ettirildiği sürece yere özgü kimliğin korunması mümkün olacaktır. Mevcutta var olan, yerel halk ve turistlerin ilgisini karşılamayan el sanatları müzelerinin işlevlerinin artırılması amaçlı tanıtımlarının yapılması gerekmektedir. Kültürel miras varlığının korunması adına yapılan düzenlemeler ile beraber dokumacılığın aile ölçeğinde ve geleneksel tarzda sürdürülmesinin desteklenmesi amaç tutulmadığı sürece bu izler kaybolacaktır. Böyle bir durumun gerçekleşmemesi adına ticaret ve turizm ağırlıklı sektörel stratejilerin mekânsal altyapılar ile desteklenmesi ile yöre halkının var olan sosyal-kültürel ve teknik altyapı yoksunluk ve yoksulluğunun giderilmesine fayda sunacağı gibi doğabilecek göç olgularının da iş olanaklarının çeşitlenmesi ile bu göç olgusunun azaltılması sağlanacaktır. Yerli ve yabancı turistler için kısıtı sayıda bulunan konaklama alanı için çözüm önerisi getirilerek ticaret koridorunun oluştuğu bölgede konaklama ihtiyacını karşılayacak alan önerisi getirilmiştir. Yerleşmenin merkezinde konumlanan otogar alanının ise yerleşmenin ihtiyacını karşılamaması ve günümüz şartlarını içermeyen eskimiş durumda bulunmasından kaynaklı sağlıklaştırma çalışmaları yapılacaktır. 
Çizelge 5. Sürdürülebilirlik Prensipleri ve Buldan Sürdürülebilirlik Modeli

\begin{tabular}{|c|c|c|}
\hline YAKLAŞIMLAR & PRENSIPLER & BULDAN YERLEŞiMI PLAN KARARLARI \\
\hline \multirow{5}{*}{ ÇEVRESEL } & $\begin{array}{l}\text { Doğal ekosistemin devamlılığı ve } \\
\text { biyolojik çeşitliliğin korunması }\end{array}$ & $\begin{array}{l}\text { Kuru dere ve çevresinde ekolojik koridor } \\
\text { oluşturulmuştur. }\end{array}$ \\
\hline & $\begin{array}{l}\text { Tabii kaynak kullanımının desteklenmesi, } \\
\text { Enerji tasarrufu sağlanması }\end{array}$ & \multirow{2}{*}{$\begin{array}{l}\text { Merkezler kademelenmesi } \\
\text { oluşturulmuştur. }\end{array}$} \\
\hline & $\begin{array}{l}\text { Üretim ve tüketimde ekolojik ayak izinin } \\
\text { en aza indirgenmesi }\end{array}$ & \\
\hline & $\begin{array}{l}\begin{array}{l}\text { Atık-geri dönüşüm döngüsünün } \\
\text { kurulması }\end{array} \\
\end{array}$ & $\begin{array}{l}\text { Geri dönüşüm politika ve kararları yerel } \\
\text { yönetim tarafından ortaya konmalıdır. }\end{array}$ \\
\hline & Dengeli nüfus artışı & $\begin{array}{l}\text { - Kompakt yerleşim kurgusu } \\
\text { - Kent merkezi ve yakın çevresindeki } \\
\text { konut bölgeleri yüksek yoğunluklu konut } \\
\text { bölgesi olup yerleşmenin çeperine doğru } \\
\text { gidildikçe düşük yoğunluklu konut } \\
\text { bölgeleri olarak önerilmiştir. }\end{array}$ \\
\hline \multirow{4}{*}{$\begin{array}{l}\text { MEKÂNSAL } \\
\text { YAPIYA DAIR }\end{array}$} & Kontrollü arazi kullanımı & $\begin{array}{l}\text {-Merkezler } \quad \text { kademelenmesi } \\
\text { oluşturulmuştur. } \\
\text {-Otogar alanının sağlıklaştırılması }\end{array}$ \\
\hline & $\begin{array}{l}\text { Sağlıklı ve güvenilir mekânların } \\
\text { oluşturulması }\end{array}$ & $\begin{array}{l}\text {-Merkezler } \\
\text { oluşturulmuştur. } \\
\text {-Bütüncül mekânsal kullanım kararları } \\
\text { alınmıştır. }\end{array}$ \\
\hline & $\begin{array}{l}\text { Ulaşımda ekolojik ayak izi düşürmek } \\
\text { (bisiklet kullanımını artırmak, yürüme ve } \\
\text { toplu taşıma sistemi) }\end{array}$ & $\begin{array}{l}\text { Ulaşım kademelenmesi ve çeşitliliği } \\
\text { oluşturulmuştur. }\end{array}$ \\
\hline & $\begin{array}{l}\text { Koruma-kullanma dengesi sağlanması } \\
\text { tarihsel kimliğin mekânda korunması }\end{array}$ & $\begin{array}{l}\text { - Yenileme müdahale çalışmaları ile } \\
\text { sokak sağlıklaştırma, çevre } \\
\text { sağlıklaştırma, kentsel tasarım projeleri } \\
\text { ve peyzaj ögelerinin de sosyo-kültürel } \\
\text { yaşantının yükseltilmesi hedefi } \\
\text { bağlamında müdahale yöntemleri } \\
\text { hedefleyen alanlar belirlenmiştir. } \\
\text { - Dokuma müzesi ve el sanatları } \\
\text { merkezleri arasında bağlantı aksı } \\
\text { oluşturulmuştur. }\end{array}$ \\
\hline \multirow{2}{*}{$\begin{array}{l}\text { EKONOMIK } \\
\text { YAPIYA DAIR }\end{array}$} & $\begin{array}{l}\text { Üretim ve tüketimde yeni teknolojik } \\
\text { çözümler üretmek }\end{array}$ & $\begin{array}{l}\text { Yerleşmedeki üniversite ve dokuma } \\
\text { tekstil atölyelerinin devamlılığı sağlanmış } \\
\text { ve ilişkisi kurulmuştur. }\end{array}$ \\
\hline & $\begin{array}{l}\text { Dengeli ekonomik } \quad \text { büyümenin } \\
\text { sağlanması }\end{array}$ & $\begin{array}{l}\text { - Dokuma müzesi ve el sanatları } \\
\text { merkezleri arasında bağlantı aksı } \\
\text { oluşturulmuştur. } \\
\text {-Konaklama alanı oluşturulması }\end{array}$ \\
\hline \multirow{4}{*}{$\begin{array}{l}\text { KÜLTÜREL } \\
\text { YAPIYA DAIR }\end{array}$} & Sosyo-kültürel değerlerin korunması & $\begin{array}{l}\text { Dokumacılığın aile ölçeğinde ve } \\
\text { geleneksel tarzda sürdürülmesinin } \\
\text { desteklenmesi }\end{array}$ \\
\hline & Yerel kimliğinin önceliğe alınması & $\begin{array}{l}\text { Geleneksel Buldan evlerinin korunması } \\
\text { mekânsal bütünlük içinde marka olarak } \\
\text { öne çıkması }\end{array}$ \\
\hline & Yerel ürünler sistemi oluşturulması & $\begin{array}{l}\text {-Tarım alanlarının korunması } \\
\text {-Yerleşime özgü ürünlerin (bağcılık, } \\
\text { meyvecilik vb.) yetiştirilmesi mekânsal } \\
\text { alanların korunması ve yeni alanların } \\
\text { oluşturulması. }\end{array}$ \\
\hline & Kültürel ekosistemin devamlılığı & $\begin{array}{l}\text { Dokumacılığın aile ölçeğinde ve } \\
\text { geleneksel tarzda sürdürülmesinin } \\
\text { desteklenmesi }\end{array}$ \\
\hline
\end{tabular}




\section{Sonuç}

Sürdürülebilirlik, kentlerde meydana gelen yoksunluk ve yoksulluğun azaltılarak, sağlıklı mekânların oluşturulmasına dönük hedefleri içeren günümüzde sıkça karşılaşılan ve sorunların çözümüne yönelik ve yerel kimliğin, gelecek nesillerin hak ve adaleti de göz önünde bulundurularak korunmasına yönelik kriterler geliştirilmesi açısından önemlidir.

Bugünün kentlerine bakıldığında sürdürülebilir kent olma yönünde kendine hedefler belirleyen kentler daha yaşanabilir kentler olarak listelenmektedir. Bu hedefleri temel alan adımların atılmadığı kentlerde hızlı nüfus artışıyla beraber kentsel yığılmalar meydana gelmekte dengesiz arazi kullanımı görülmektedir. Kentsel yığılmalar beraberinde doğal çevre koşullarının yıprandığı, biyolojik çeşitliliğin zarar gördüğü ve sağlıksız yaşam koşullarını doğuran, beslenme ve kıtlık sorunlarının oluştuğu, yerel ve kültürel değerlerin kaybedildiği kimliksiz ve planlama sorunları bulunan kentler olarak kent plancıların karşısına çıkmaktadır.

Çalışmada, Buldan yerleşmesinde var olan tarihsel, kültürel ve doğal miras değerlerinden oluşan mekânsal ve işlevsel kurgusuna yönelik yerel ve kültürel değerlerin gelecek nesillerin hak ve yararı gözetilecek şekilde düşünülerek yerel ürünler sistemi oluşturulması, Buldan'da dokumacılığın aile ölçeğinde ve geleneksel üretimin sürdürülmesini sağlayarak ekonomik kalkınmanın sağlanması hedeflenmiştir. Yapılan araştırmalar kapsamında Buldan'da özgün yerel kimliğin korunarak, yöreye özgü geleneksel bağın koparılmadan yerleşmede güvenlikli mekânların oluşturulması ve doğal yaşama ortamlarının korunması, kentsel sürdürülebilirlik için büyük bir önem taşımaktadır.

Kentsel sürdürülebilirlik sağlanması adına model yaklaşımında önerilen, mekânsal-işlevsel gelişmeleri ile geleceğe dönük koruma-geliştirme potansiyellerinin dikkate alındığı, sahip olunan özgün yerel değerlerin korunarak, kentlerin tarihsel bilgileri eşliğinde çevresi ile bütüncül yaklaşımların ele alınması önem taşımaktadır. Sosyal yaşantıda farkındalık yaratarak bilinçli toplumlar kazanımı sağlanmalı, kaynak kullanımında etik süreci de gözetilerek tüm toplumun eşit biçimde yararlanması sağlanmalı ve ulaşım araçları arasında entegrasyonun sağlanarak sürdürülebilir ulaşımın tüm kesim için daha kolay ve verimli hale getirilmesi, kent ve kentte yaşayanlar için önemlidir. Çevresel süreç olarak bakıldığında ise, mevcut kaynak akışındaki kısıtlamaların dikkate alınarak tabii kaynakların bilinçli ve bilinçsiz tüketiminin ortadan kaldırıması bugün ve gelecek kuşak adına önem teşkil etmektedir. Sürdürülebilirlik adına yapılan çalışmalar tek bir boyut olarak değil, mekânsal, ekonomik, sosyo-kültürel, ekolojik, kurumsal anlamda politika ve stratejilerin birbirleri ile çelişmeyen, birinin yararı olarak değil, tümünün uyum sağladığı, tüm kesim için eşit fayda sağlayan bir süreç şeklinde ele alınması gerekmektedir. Sürdürülebilirliğin sağlanması adına ilgili kurumların destekleri ile gerekli kurum ve derneklerin kurulması sağlanarak kurumların, halkın bilinçli ve etkin katılımının sağlanması amaçlı destek ve gönüllülük projeleri ile katkı sağlamalıdır. Çevre ve hava kirliliğini önleme adına bireysel ve toplumsal yarar sağlayan projeler geliştirilmelidir.

\section{Kaynaklar}

Anonim, (1987). Our Common Future: the Brundtland Report, World Commission on Environement and Developement, Oxford University Press.

Attwell, K. (2000). Urban land resource and urban planting-Case studies from Denmark Landscape and Urban Planning, 52 (2000), pp. 145-163.

Broman, G. I., Robèrt, K. H. (2017). A framework for strategic sustainable development. Journal of Cleaner Production, 140, 17-31.

Burgess R., Carmona M., Kolstee T. (1997). The challenge of sustainable cities, Zed Books, London.

Çal, í. (2012). Yerel verilerin geleneksel mimari üzerindeki etkilerinin sürdürülebilirlik bağlamında karşılaştııılmalı olarak incelenmesi: Akseki-ibradı ve Piemonte-Val D’Ossola örneği.

Desheng, X., Gengzhi H., Jingwen G., Jiarong L. (2014). Changing concepts of city and urban planning practices in guang-zhou(1949-2010): An approach to sustainable urban development.

Ekim, D. (2004). Sürdürülebilirlik kavramı ve mimari form üzerindeki etkisi, İstanbul Teknik Üniversitesi, Fen Bilimleri Enstitüsü, Mimari Tasarım Lisansüstü Programı, Yayınlanmamış Yüksek Lisans Tezi. 
Eser, S., Dalgın, T., \& Çeken, H. (2010). Sürdürülebilir kültür turizmi: Efes örneği. Ege Coğrafya Dergisi, 19(2), 2734.

Gazibey, Y., Keser, A., Gökmen, Y. (2014). Türkiye'de illerin sürdürülebilirlik boyutları açısından değerlendirilmesi.

Harris, N. (1992). Wastes, the environment and the international economy, Cities, 9 (3), pp. 177-185.

Karakurt Tosun, E. (2009). Sürdürülebilirlik olgusu ve kentsel yapıya etkileri. PARADOKS Ekonomi, Sosyoloji ve Politika Dergisi, 5(2), 1-14.

Karakuzulu, Z. (2010). Sürdürülebilir Kentler ve Kasabalar, Yerel Gündem 21 ve Bursa Örneği. TÜCAUM VI. Ulusal Coğrafya Sempozyumu 3-5 Kasım 2010 Bildiri Kitabı, 397-406.

Liv, H., Zhou, G., Wennersten, R., Frostell, B. (2014). Analysis of sustainable urban development approaches in China.

Maimaitiyiming, M., Ghulam, A., Tiyip, T., Pla, F., Latorre Carmona, P., Halik, U., Sawut, M., Caetano, M. (2014). Effects of green space spatial pattern on land surface temperature: Implications for sustainable urban planning and climate change adaptation.

Mansuroğlu, S., Kınıklı, P., Saatcı, B. (2012). Antalya'da kentsel gelişimin ekolojik açıdan değerlendirilmesi ve sürdürülebilirlik kapsamında önerilerin geliştirilmesi.

Marcotullio, P.J. (2001). Asian urban sustainability in the era of globalization, Habitat International, 25 (4), pp. 577-598.

May A.D., Mitchell G., Kupiszewska D., (1997), The development of the leeds quantifiable city model, P.S. Brandon, P.L. Lombardi, V. Bentivegna (Eds.), Evaluation of the built environment for sustainability, E \& FN Spon, London, pp. 39-52.

Medved, P. (2016). A contribution to the structural model of autonomous sustainable neighbourhoods: New socio-economical basis for sustainable urban planning.

Özcan, K. (2009). Sürdürülebilir Kentsel Korumanın Olabilirliği Üzerine Bir Yaklaşım Önerisi: Konya Tarihi Kent Merkezi Örneği. METU Journal of the Faculty of Architecture, 26(2).

Özcan, K. (2016). Kent Planlamada Sürdürülebilirlik Gündemi: Bir Kavramsallaştırma Denemesi. Avrasya Terim Dergisi, 4(2), 7-17.

Temur, H. (2011). Edirne geleneksel konut mimarisinin sürdürülebilirlik bağlamında enerji verimliliği ve ısıl analiz açısından değerlendirilmesi, Trakya Üniversitesi, Yayınlanmamış Yüksek Lisans Tezi.

Tosun Karakurt. E. (2013). Sürdürülebilir kentsel gelişim sürecinde kompakt kent modelinin analizi. Dokuz Eylül Üniversitesi Sosyal Bilimler Enstitüsü Dergisi, 15(1), 103-120.

Tuğun, Ö., \& Karaman, A. (2014). Çekirdek Köylerin Eko Turizme Kazandırılması İçin Sürdürülebilirlik Kavramı Çerçevesinde Bir Model. Megaron, 9(4).

United Nations Population Fund (2007). State of world population 2007: Unleashing the potential of urban growth. United Nations Population Fund, New York.

UN Habitat, (2009) , Urban indicator guidelines, "Better Information, Better Cities", https://unhabitat.org

Roy, M. (2009). Planning for sustainable urbanization in fast growing cities: Mitigation and adaptation issues addressed in Dhaka, Bangladesh, Habitat International, 33 (3) (2009), pp. 276-286.

Shen, L., Peng, Y., Zhang, X., Wu, Y. (2012). An alternative model for evaluating sustainable urbanization. Cities, 29(1), 32-39.

Shen, L., Zhou, J. (2014). Examining the effectiveness of indicators for guiding sustainable urbanization in China. Habitat International, 44, 111-120.

Siiba, A., Adams, E. A., Cobbinah, P. B. (2018). Chieftaincy and sustainable urban land use planning in Yendi, Ghana: Towards congruence. Cities, 73, 96-105.

Yigitcanlar, T., \& Teriman, S. (2015). Rethinking sustainable urban development: towards an integrated planning and development process. International Journal of Environmental Science and Technology, 12(1), 341-352. 
Wu, J. (2014). Urban ecology and sustainability: The state-of-the-science and future directions. Landscape and Urban Planning, 125, 209-221. 